Portland State University

PDXScholar

7-1-1970

\title{
A survey of hearing loss in the special education classrooms of Vancouver School District 37
}

Richard C. Folsom

Portland State University

Follow this and additional works at: https://pdxscholar.library.pdx.edu/open_access_etds Let us know how access to this document benefits you.

\section{Recommended Citation}

Folsom, Richard C., "A survey of hearing loss in the special education classrooms of Vancouver School District 37" (1970). Dissertations and Theses. Paper 944.

https://doi.org/10.15760/etd.944

This Thesis is brought to you for free and open access. It has been accepted for inclusion in Dissertations and Theses by an authorized administrator of PDXScholar. Please contact us if we can make this document more accessible: pdxscholar@pdx.edu. 


\begin{abstract}
AN ABSTRACT OF THE THESIS OF Richard C. Folsom for the Master of Science in Speech with a major emphasis in Audiology and Speech Pathology presented July 13, 1970.
\end{abstract}

Title: A Survey of Hearing Loss in the Special Education Classrooms of Vancouver School District 37.

\title{
APPROVED BY MEMBERS OF THE THESIS COMMITTEE:
}
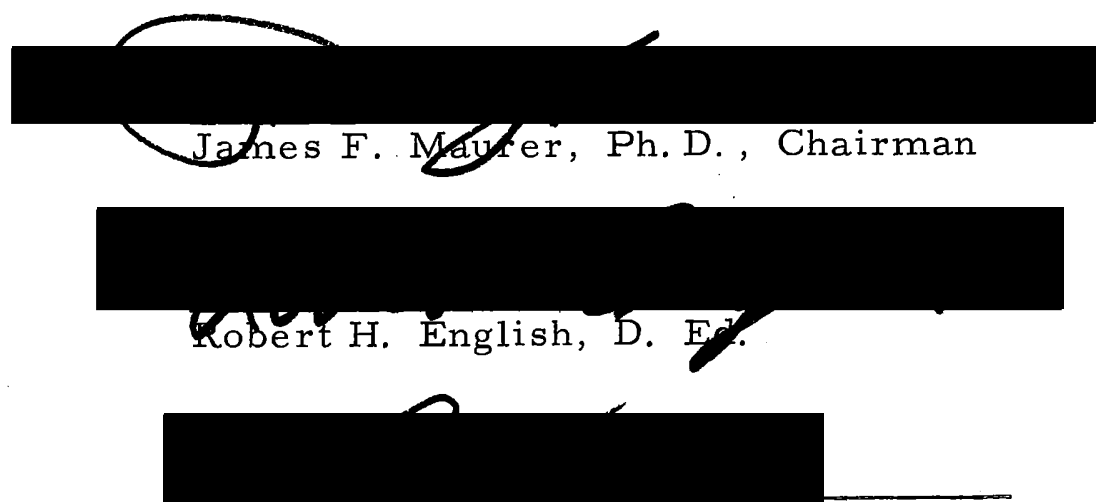

F. Paul Ventura, Ph. D.

In order for the mentally retarded population to achieve maximum benefit from rehabilitation efforts, it is essential that a complete picture of their abilities and disabilities be obtained. Consequently, the identification of hearing loss is an integral element in. any diagnostic procedure. Vancouver School District 37 has directed increased attention toward speech and language training for children in the special education classrooms for the mentally retarded; 
however, differential hearing diagnosis has been inadequate or totally lacking.

In order to more efficiently treat this problem, it was felt that a comprehensive investigation into the incidence and types of hearing loss of this population would provide a basis for program design. To adequately survey the previous investigations in the literature, it was advantageous to divide them into categories according to likeness of criteria used in defining. "hearing loss."

In this survey, a heterogeneous sample of 212 retarded subjects ranging in age from 6 years, 8 months to 19 years, 9 months was audiometrically tested at four frequencies: $500 \mathrm{~Hz}, 1000 \mathrm{~Hz}$, $2000 \mathrm{~Hz}$, and $4000 \mathrm{~Hz}$. The retarded subjects encompassed MI levels I through IV on the classification system developed by the American Association on Mental Deficiency. Tests were administered at eight locations within the Vancouver School District 37 which offered adequate test environments. The criterion for hearing loss in this survey was a los of $20 \mathrm{~dB}$ or more in two or more frequencies in either ear. The audiometric procedure used in both airand bone-conduction testing was the revised technique of Newhart and Reger (1945, revised 1956). Operant procedures were designed after Stewart (1970). Two examiners were used, and ten test scores of each correlated at approximately.93 using the Pearson ProductMoment Correlation. 
Thirty-eight of the 212 subjects had hearing losses of $20 \mathrm{~dB}$ or more in two or more frequencies in either ear. This number established an incidence of 17.9 per cent for this population. The present data indicate, in general, that the incidence of hearing los is greater among the more severely retarded than among the less retarded. The audiometric data depict a general trend toward a decrease in hearing loss incidence with increasing age. Of those with hearing loss, slightly more males (53 per cent) than females (47 per cent) were represented. The pattern established by the current survey revealed a concentration of conductive losses at lower age levels and a concentration of sensori-neural losses at the higher age levels.

The special education classrooms of Vancouver School District 37 reveal a three to six times greater incidence of hearing los than among the normal classrooms of the district. The concentration of conductive losses at lower age levels leads to a recommendation that hearing levels be screened each year up to age 12 . 
A SURVEY OF HEARING LOSS IN THE SPECIAL EDUCATION

CLASSROOMS OF VANCOUVER SCHOOL DISTRICT 37

by

RICHARD C. FOLSOM

A the sis submitted in partial fulfillment of the

requirements for the degree of

\author{
MASTER OF SCIENCE \\ in \\ SPEECH \\ with major emphasis in Audiology \\ and Speech Pathology
}

Portland State University

1970 
TO THE OFFICE OF GRADUATE STUDIES:

The members of the Committee approve the thesis of

Richard C. Folsom presented July 13, 1970.
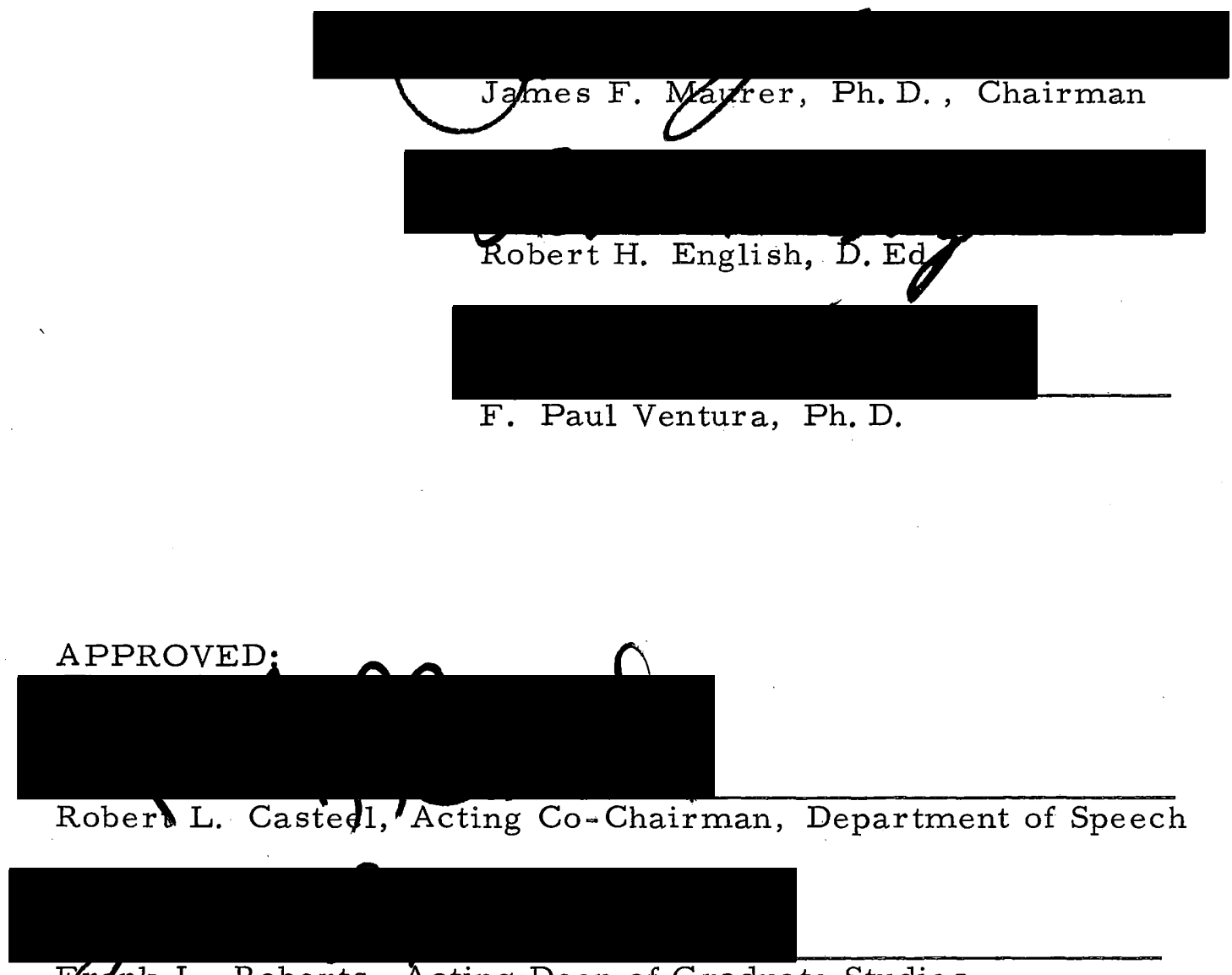

F/r lnk L. Roberts, Acting Dean of Graduate Studies

July 15, 1970 


\section{A CKNOW LEDGMENTS}

Most sincere appreciation is expressed to Dr. James F.

Maurer for his understanding, direction, and support in the development of this manuscript.

Gratitude also is expressed to Miss Connie Stelter of the Vancouver School District 37 Speech and Hearing Department for her assistance in the collection of data and to Mr. Robert E. Rylander, Coordinator of Speech and Hearing Services, Vancouver School District 37, for his cooperation and time in this endeavor. 
TABLE OF CONTENTS

PAGE

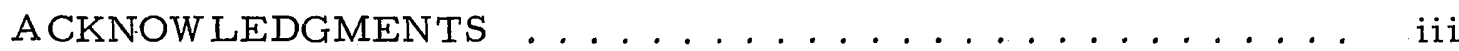

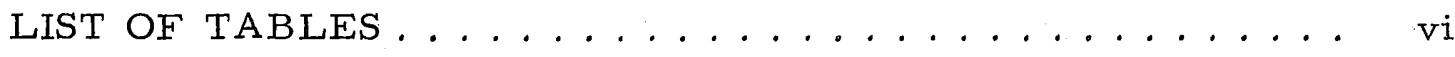

LIST OF FIGURES .................... vii

\section{CHAPTER}

I INTRODUCTION . . . . ............ 1

II HISTORY OF THE PROBLEM .......... 4

A Loss of $20 \mathrm{~dB}$ or More for One or

More Frequencies in Either Ear ..... 4

A Loss of $20 \mathrm{~dB}$ or More for Two or

More Frequencies in Either Ear .... 8

A Loss of $30 \mathrm{~dB}$ or More for One or

More Frequencies in Either Ear ..... 12

Criteria Which Have Not Been

Replicated .............. 13

III STATEMENT OF THE PROBLEM . . . . . . . . 23

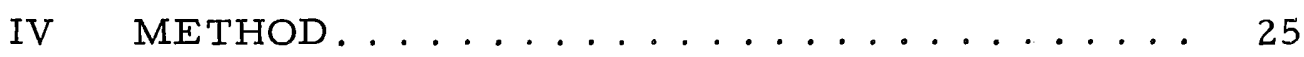

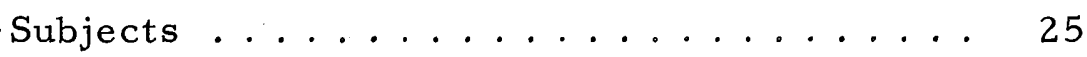

Intelligence

Chronological Age

Physiologic and Sensory Factors

Test Room and Equipment .......... 29 
Selection of Stimuli.............. 31

Conditioning and Reinforcement....... 31

Procedures...................... 32

Criteria for Hearing Loss

Air-Conduction Tests

Bone-Conduction Tests

Masking for Air-and Bone-Conduction

Operant Procedures

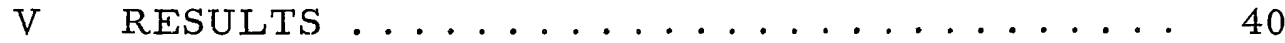

Hearing Loss in Relation to MI Level ..... 40

Hearing Loss in Relation to Age Level .... 42

Hearing Loss in Relation to Sex ....... 42

Hearing Loss in Relation to Type ....... 42

VI $\quad$ DISCUSSION $\ldots \ldots \ldots \ldots \ldots \ldots$

VII SUMMARY AND CONCLUSIONS ......... 53

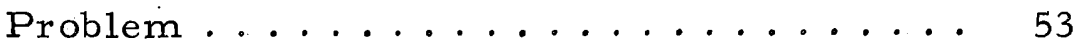

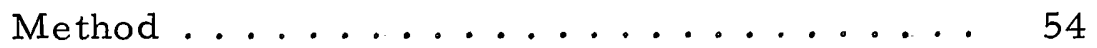

Results ..................... 54

Conclusions...................... 55

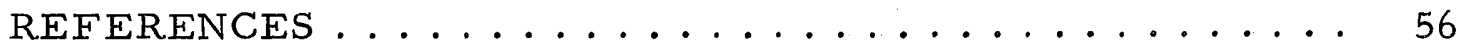

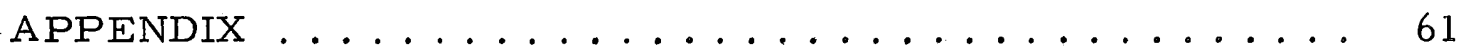




\section{LIST OF TABLES}

TABLE

PAGE

I AAMD Classification of Mental Retardation ...... 2

II Comparison of Data on Hearing Loss Incidence

in Mental Retardates.............. . . 19 


\section{LIST OF FIGURES}

FIGURE

PAGE

1 Total Number of Male and Female Subjects at

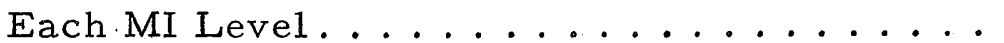

2 Total Number of Male and Female Subjects at

Each Age Leve1 .................. 28

3 Percentage of Subjects with Hearing Loss at

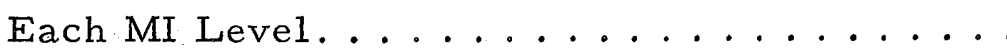

4 Percentage of Subjects with Hearing Loss at

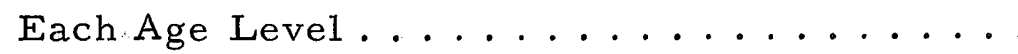

5 Percentage of Male and Female Subjects with

Hearing Loss at Each MI Level ......... 44

6 Percentage of Male and Female Subjects with

Hearing Loss at Each Age Level........ 45

7 Percentage of Subjects with Hearing Loss by

Type at Each Age Leve1............. 46 


\section{CHAPTER I}

\section{INT RODUCTION}

It is clear that no definitive answers can be brought to light to statistical questions concerning the nationwide prevalence of intellectual subnormality. A generally accepted estimate of mental retardation has been a minimum appraisal of about $3 \%$ of the general population (Robinson and Robinson, 1963). This estimate would project the number of mentally retarded individuals in the United States at between five and six million. Most of these are children (Weber, 1963; Gardner, 1967).

The retarded population constitutes a very heterogeneous group both with respect to the variegated causes of deficiencies and the various levels of social communication (Robinson and Robinson, 1963). Because of the variety of intellectual behaviors, systems of classification have been developed. The American Association on Mental Deficiency has categorized mental retardates according to their level of impairment in measured intelligence (Heber, 1959; revised, 1961). (See Table I.)

In order for this population to achieve maximum benefit from rehabilitation efforts, it is essential that a complete picture of their 
TABLE I

AAMD CLASSIFICATION OF MENTAL RETARDATION

\begin{tabular}{|c|c|c|c|c|}
\hline \multirow{2}{*}{$\begin{array}{l}\text { Measured } \\
\text { Intelligence } \\
\text { (MI) } \\
\text { Level of } \\
\text { Deviation }\end{array}$} & \multirow[b]{2}{*}{ Description } & \multirow{2}{*}{ SD Range } & \multicolumn{2}{|c|}{ IQ Range } \\
\hline & & & Binet & Wechsler \\
\hline I & Borderline & -1.01 to -2.00 & $68-83$ & $70-84$ \\
\hline II & Mild & -2.01 to -3.00 & $52-67$ & $55-69$ \\
\hline III & Moderate & -3.01 to -4.00 & $36-51$ & $40-54$ \\
\hline IV & Severe & -4.01 to -5.00 & $20-35$ & $25-39$ \\
\hline $\mathrm{V}$ & Profound & Below -5.00 & Below 20 & Below 25 \\
\hline
\end{tabular}

abilities and disabilities be obtained. It is well known that mental retardation may be accompanied by additional handicaps such as varying degrees of cerebral palsy, impairment of sight, and other physical disabilities. Many of these conditions are obvious even on superficial examination. Hearing loss, on the other hand, may remain undetected and interfere with the educational program of the child.

Careful and accurate diagnostic procedures would prevent a deaf or hard-of-hearing child from being mistakenly labeled as "mentally retarded" when that child may actually have adequate learning potential (Lillywhite and Bradley, 1969). Even when the 
label "mentally retarded" is not challenged, an adequate assessment of hearing level can contribute vital information for educational direction and, in some cases, medical treatment.

A retardate also may be disproportionally handicapped by a given amount of hearing impairment, making its identification that much more important (Frisina and Lloyd, 1965; Lillywhite and Bradley, 1969). It is possible, for example, that a retarded child's ability to acquire language would be affected to a greater degree by a given hearing loss than would a nonretarded child who has an equal amount of hearing loss. Identification of hearing loss is important for any child, but in the mentally retarded child it is especially important because of the number of concomitant problems (Lillywhite and Bradley, 1969). 


\section{CHAPTER II}

\section{HISTORY OF THE PROBLEM}

A review of the literature and related research in previous incidence studies noted that a major point of variation between investigators was the difference of criteria used in defining "hearing loss." To adequately survey the previous investigations, it would seem advantageous to divide them into categories according to likeness of criteria used in defining "hearing loss" and review each study:according to test procedure, response class, age range of sample, IQ range, etc., when such information is available.

It has been found convenient to divide the investigations into four groups (Webb, et al., 1964): Group I, a loss of $20 \mathrm{~dB}$ or more for one or more frequencies in either ear; Group II, a loss of $20 \mathrm{~dB}$ or more for two or more frequencies in either ear; Group III, a loss of $30 \mathrm{~dB}$ or more for one or more frequencies in either ear; and Group IV, criteria which have not been replicated.

I. A LOSS OF $20 \mathrm{~dB}$ OR MORE FOR ONE OR MORE FREQUENCIES IN EITHER EAR

Birch and Matthews (1951) surveyed the hearing los of institutionalized mental retardates at the Polk State School, Polk, 
Pennsylvania. They decided to select cases from the ages of 10 to 19 for inclusion in the study. This included 247 cases. The median IQ was 49 with a high of 58 and a low of 42 . The median mental age at the time of testing was 7-0 years.

The subjects were tested by conventional audiometric techniques which allow the audiometrist to arrange the subject for a standard response to indicate whether a tone is heard or not. The response for this study: was hand raising and lowering. An adaption of the sweep-check method was used to provide a pass-fail criterion for hearing testing. When a subject failed to hear a given tone at 15 $\mathrm{dB}$, the tone was increased in loudness until it was heard, thus, providing threshold measures for each subject of the frequencies where hearing loss of more than $15 \mathrm{~dB}$ was found. All tests were administered at ASA (1951) reference levels. Over one-half of the group ( $55 \%$ ) had losses of $20 \mathrm{~dB}$ or more at one or more of the frequencies tested $(512-8192 \mathrm{~Hz})$.

Foale and Paterson (1954) describe the hearing status of 100 mentally retarded boys at the Lennox Castle Institution for Mental Defectives in Scotland. They selected boys whose ages ranged from 10 to 19 years for inclusion in the study. The mean IQ for the 100 retardates was 66.

The tests were conducted in a room at the institution with a "very low" noise level. All were tested on a standard pure tone 
audiometer. Conventional audiometry was used to obtain the hearing tests. The response class was saying. "yes" when a tone was presented. The tones were presented to the subjects at an intensity of $10 \mathrm{~dB}$. Any tone not heard at this level of intensity was increased in loudness until it was responded to by the child. All tests were administered at ASA (1951) reference levels. Of the 100 Lennox Castle boys tested, $67 \%$ had good hearing in both ears, which leaves $33 \%$ of the group with $20 \mathrm{~dB}$ or more loss at one or more of the frequencies tested.

Siegenthaler and Krzywicki (1959) tested the hearing of school and "non-school" girls at the institution for potentially delinquent females of child bearing age in Laurelton, Pennsylvania. Those classified as non-school girls were those who were uneducable or unlikely to ever be able to live outside of an institution regardless of age or IQ. The girls classified as school girls were those in education or training programs who might sometime receive discharge from the institution.

Siegenthaler and Krzywicki selected 396 school girls and 242 non-school girls. The school girls ranged in age from $14-46$ years with a mean age of 21.7 years. The non-school girls ranged in age from 22-47 years with a mean age of 35.0 years. The school girls' IQ scores ranged from 44-84 with a mean IQ of 52.4 and the nonschool girls' IQ scores ranged from 44-84 with a mean IQ of 51.0 . 
The girls were screened through at $15 \mathrm{~dB}$ HL for frequencies 250 through $4000 \mathrm{~Hz}$. All tests were administered at ASA (1951) reference levels. The testing procedures followed the conventional techniques as much as possible. Hand raising was the response class required of most of the subjects. Modifications were necessary for some of the individuals who found it difficult to respond by hand raising. In such cases, the tester conditioned and reconditioned the subject verbally and visually as well as auditorially at intervals throughout the test. Hearing loss incidence for the two groups of subjects was $17 \%$ for the school girls and $32 \%$ for the non-school girls.

Lloyd and Reid (1967) presented audiometric data on the population of mentally retarded children at Parsons State Hospital and Training Center, Parsons, Kansas. They surveyed the total population of the Parsons State Hospital and Training Center as of September 1, 1965. The patient population at that time was 638 children (288 females and 350 males) between the ages of 6 and 22 years. This population represented the full range of measured intelligence (MI) described by' Heber (1961).

The screening tests were administered in acoustically treated, auditory testing rooms (IAC, model 800). All patients were given a $15 \mathrm{~dB}$ pure tone screening test of the frequencies $250-8000 \mathrm{~Hz}$. Relatively conventional audiometric techniques such as the standard 
hand raising were used. Ear choice, play, and slide-show techniques were used on patients as deemed appropriate by the tester. Of the 638 children tested at Parsons, $19 \%$ had hearing loss of $20 \mathrm{~dB}$ or more for one or more frequencies in either ear.

Marshall (1967) gathered hearing data on 200 mentally retarded children who passed through the Multi-Discipline Clinic at the University of Oregon Medical School. Of the 200 children reviewed, the age range was 2 years to 13 years 6 months. Eighty-two of the children were female and 119 of them were male.

Audiometric tests were carried out at the Clinic using a variety of techniques. For the higher grade retardates, conventional audiometric techniques were used. Patients classified as DTT (difficult to test) demanded further as sessment procedures in conditioning audiometry. All tests were administered at ISO (1964) reference levels. The hearing loss incidence among this group of retardates was $17 \%$.

\section{A LOSS OF $20 \mathrm{~dB}$ OR MORE FOR TWO OR MORE} FREQUENCIES IN EITHER EAR

Johnston and Farrell (1954) surveyed the hearing of mentally retarded subjects in the educational department of the Fernald State School in Massachusetts. The 270 resident children selected constituted a mean age of 13.2 and a mean IQ of 60.2. The average 
length of institutionalization was 39.2 months.

All hearing test activities were carried out in a "quiet" classroom area. The subjects were tested by standard audiometric methods and the response class in this survey was hand raising. Individual discrete frequency audiograms covering the frequency range $250 \mathrm{~Hz}$ through $6000 \mathrm{~Hz}$ were obtained. Hearing tests were given to a group of 270 resident children who regularly attended academic classes. The incidence of referable hearing impairment in this portion of the Fernald population was extremely high relative to public school rates. Of the 270 children, 66 children or $24 \%$ showed significant hearing losses.

Schlanger and Gottsleben (1956) reported on the results of testing mentally retarded children at the training school at Vineland, New Jersey. Four hundred ninety-eight mentally retarded subjects were used. The subjects were divided into two groups for this survey. Group one contained those 5-20 years of age, and group two contained those over 20 years of age. This division was made to separate, to a certain extent, the effects of advancing age on hearing acuity. Beasley (1940) pointed out that from a C. A. of 20 years, the incidence of hearing loss in mental retardates increases markedly and continues to rise in direct relation to age. There were $210 \mathrm{sub}-$ jects below C.A. 20 years. The mean age of this group was 13.9 years. The older group consisted of 288 subjects whose mean. C. A. 
was 39.6 years. The mean chronological age for the two groups together was 28.9 years and the mental age was 7.8 years.

Schlanger and Gottsleben modified the usual audiometric techniques used in hearing evaluation. A longer training period than normal was established so that hand signal responses to the stimuli could be learned. During the learning period, intensity levels of $50 \mathrm{~dB}$ were fed into each ear at the three frequencies, 250, 1000, and $3000 \mathrm{~Hz}$, so that the subjects were acquainted with the listening task. All tests were administered at ASA (1951) reference levels. In the event that no responses were obtained, dB levels:were raised. The training period was also a warm-up period in which fears were reduced and motivation increased. The frequency rate of $125 \mathrm{~Hz}$ through $12000 \mathrm{~Hz}$ was tested. The incidence of hearing loss for the entire group was $43 \%$

Rigrodsky, Prunty, and Glovsky (1961) surveyed the incidence of hearing loss in the institutionalized mentally retarded population at the Training School at Vineland, New Jersey. They chose 325 residents of the Training School for the study. The individuals ranged from 5 to 71 years of age. No IQ averages or mental ages were reported. It was noted that this population is not representative of the entire range of mental retardation, as subjects in this survey were of a higher socioeconomic level than the usual institutionalized mentally retarded population. 
The subjects were given pure tone air conduction and bone conduction audiometric tests. For the severely mentally retarded subjects, and many of the children who ranged in age from 4 to 8 chronologically, special conditioning techniques were used and the test was administered over several sessions to avoid distractions and fatigue. The patients were tested in a "relatively quiet" therapy room at the Training School. The frequencies tested were $250 \mathrm{~Hz}$ through $8000 \mathrm{~Hz}$. All tests were administered at ASA (1951) reference levels. The data from this survey revealed that of the 325 residents, 75 , or $25 \%$ of the population, had impaired hearing.

Webb, Kinde, Weber, and Beedle (1964) carried out hearing tests on mentally retarded subjects at the Mount Pleasant State Home and Training School in Michigan.

Conventional audiometric methods were used in this survey and the response class required was either hand raising or vocalizing "yes" in response to the pure tone stimulus. The subjects were tested over the frequencies $500-2000 \mathrm{~Hz}$. All tests were adminis tered at ASA (1951) reference levels. Of the 369 mentally retarded subjects tested at Mount Pleasant, 25\% maintained a hearing los s of $20 \mathrm{~dB}$ or more for two or more frequencies for one or both ears.

Webb, Kinde, Weber, and Beedle (1964) also carried out sound field, live voice testing on 1,093 retardates at Mount Pleasant. This procedure, which established a criteria of failure to give two 
observable responses to $20 \mathrm{~dB}$ live voice sounds, resulted in an incidence of hearing los of $24 \%$.

III. A LOSS OF $30 \mathrm{~dB}$ OR MORE FOR ONE OR MORE FREQUENCIES IN EITHER EAR

Schlanger and Gottsleben (1956) also reported their data according to these criteria after testing the 498 mentally retarded subjects reported earlier in this paper. Those frequencies tested were $125 \mathrm{~Hz}$ to $12000 \mathrm{~Hz}$, ASA. The incidence of hearing los was 25.7\% for the two age groups.

Kodman, Phillip, Powers, and Weller (1958) surveyed the hearing of mentally retarded subjects at The Kentucky Training School, Frankfort, Kentucky. They chose 208 subjects for the present study. This sample was divided into two groups on the basis of age. The first group, or young group, ranged in ages from $7-19$ years, with a mean age of 15.3 years. The average IQ for the young group was 53.06 and the mental age 6.83. The second group, or old group, ranged in ages from 20-64 years, with a mean age of 38.7 years. The average IQ of the older group was 47.8 and the mental age 6.44 .

Individual pure tone audiometry was used throughout. Conventional audiometric conditioning techniques were used; however, the response class was not noted. Each subject was screened at $20 \mathrm{~dB}$ 
ASA at six frequencies between $250 \mathrm{~Hz}$ and $8000 \mathrm{~Hz}$. If the subject failed the screening level, his pure tone thresholds were then determined for each frequency in both ears. Hearing was tested in relatively quiet testing rooms at the home. Ambient noise was found to elevate the threshold at $125 \mathrm{~Hz}$ in these testing rooms; therefore, this frequency was not included in the investigation. Based on the criterion of $30 \mathrm{~dB}$ or greater hearing loss, $21 \%$ of the 208 subjects comprised the hearing loss group. The young group incidence of hearing loss was $19.04 \%$ while that of the older group was $23.81 \%$.

\section{CRITERIA WHICH HAVE NOT BEEN REPLICATED}

Rittmanic (1959) tested the hearing of 1, 200 mentally retarded patients at the Dixon State School, Dixon, Illinois. The subjects ranged in ages from 6 years to 80 years and IQ scores ranged from 30 to 129 . The sample included 589 males and 631 females. The patients used in the hearing survey were selected on the basis of their ability to respond reliably to an individual pure tone audiometric screening test.

The frequencies tested were $250 \mathrm{~Hz}$ through $8000 \mathrm{~Hz}$. Conventional audiometric techniques were used and the response class was hand raising. The criteria for hearing loss in this survey was a loss of $15 \mathrm{~dB}$ ASA or more for two or more of the frequencies tested. All tests were administered at ASA (1951) reference levels. 
The results of auditory testing revealed a total of 495 patients (40. 5\%) with medically significant hearing losses. The incidence of referable hearing impaired cases in the 10-19 year old group was extremely, high in comparison with public school rates. Of the group of 297 residents tested in this school age group, 59 or $19.8 \%$ showed significant hearing loss.

Schlanger (1961) surveyed the hearing loss in the institutionalized mentally retarded population at St. Mary's Training School, New Jersey. The 199 subjects were all from the Training School except for 32 subjects from special classes in the public schools. Neither IQ nor chronological and mental age norms were given.

Conventional audiometric techniques were used and the subjects were given pure tone air conduction audiometric tests. For the severely retarded subjects and those very young chronologically, special conditioning techniques were used. The subjects were limited to those capable of participating in audiometric screening. The frequencies tested were $500 \mathrm{~Hz}$ through $4000 \mathrm{~Hz}$, ASA. Criterion for hearing loss was failure to respond to two frequencies at $30 \mathrm{~dB}$ or more in either ear. All tests were administered at ASA (1951) reference levels. Excluding those defined as untestable, $42 \%$ of the remaining retardates was defined as having a hearing loss.

Anderson (1964) reported on the hearing testing of the special achievement classes (educable mentally retarded) of Oregon. 
Conventional audiometric techniques were used throughout. The subjects were given pure tone air conduction and bone conduction audiometric tests. Those who could not respond to conventional audiometric testing were conditioned to the sound stimulus. The 2, 235 subjects were not preselected for this report; rather, the entire population of the special achievernent classes in Oregon was used. The frequencies tested were $500 \mathrm{~Hz}$ through $6000 \mathrm{~Hz}$, ASA. Criteria for hearing loss were a hearing level of $20 \mathrm{~dB}$ or more in the frequencies 500, 1000, and $2000 \mathrm{~Hz}$ in either ear, or an average loss of $25 \mathrm{~dB}$ in the frequencies 3000,4000 , and $6000 \mathrm{~Hz}$ in either ear. Seventeen per cent of the children tested under the above criteria were found to have a referable hearing loss.

Holmes and Peletier (1966) surveyed the hearing of 824 retardates at Pineland Hospital and Training Center in Pownal, Maine. Neither IQ nor chronological and mental age norms for the subjects were given.

The tests were conducted in a room at a "very low" noise level. Conventional audiometric techniques were used to obtain the hearing tests, which were performed on standard pure tone audiometers. The response class was hand raising or "yes" responses. The frequencies tested were $500 \mathrm{~Hz}$ through $8000 \mathrm{~Hz}$, ISO.

Criterion for hearing loss was an average threshold of $15 \mathrm{~dB}$ or poorer for the three speech frequencies 500, 1000 , and $2000 \mathrm{~Hz}$ 
in either ear. Of those patients tested under the above criterion, 20. $1 \%$ were found to have a referable hearing loss.

Fulton and Griffin (1967) reported the audiological results of 2, 290 (92. $2 \%$ of the population) residents of the Fort Wayne State Hospital and Training Center, Fort Wayne, Indiana, between the dates January: 1, 1963, and January. 1, 1966. The residents included in the report ranged in age from 6 months to 87 years with an approximate mean age of 35 years. The population was $55.5 \%$ male and $44.5 \%$ female. The population was generally divided relative to functioning level as follows: borderline-mild, $24 \%$; moderate, $44 \%$; severe-profound, 30\%; and other, $2 \%$.

Most of the subjects were tested by standard audiometric procedures; however, sound field and other techniques were used on those patients deemed difficult to test. The response class for the standard audiometric procedures was hand raising or lowering. The examinations covered the frequency range of $500 \mathrm{~Hz}$ to $8000 \mathrm{~Hz}$. The criterion for hearing loss was an average threshold of $25 \mathrm{~dB}$ of the five frequencies tested in either ear. The tests administered in the years from January: 1, 1963, to January 1, 1966, are reported according to ISO (1964) reference levels. The 2, 290 subjects tested at the Fort Wayne State Hospital and Training Center had a hearing loss incidence of $27.4 \%$. 
Data on the incidence of hearing impairment among mentally retarded children obviously vary greatly. These variations of incidence have been associated with characteristics of the child, the criteria or definition for "hearing loss," as well as several other factors (Lloyd and Frisina, 1965).

The influence of retardation or a factor common to retardation has been suggested as a variable by Lloyd and Frisina (1965) and Webb et al. (1966). Siegenthaler and Krzywicki (1959), however, did not find the presence of hearing loss to be significantly related to IQ. Using product moment and partial correlations to compute relationships between hearing loss incidence, IQ, and chronological age, the latter authors found no significant relationships. Lloyd and Reid (1966) reported only a slightly better test-retest agreement between retardates of higher and lower levels. Lloyd, Reid, and McManis (1968) also found no relationships between the size of test-retest difference and IQ.

Differences in criteria used to determine hearing loss also have been related to the variations of the incidence reported. Webb et al. (1966) found that the incidence among retardates tends to increase as a function of the stringency of the criteria for "hearing loss."

Other factors which may cause variability among incidence figures are characteristics of the testing environment (Lloyd and 
Frisina, 1965), variations in audiometer performance (Doerfler and Eagles, 1961), and differences between American Standards Association (ASA) reference levels of 1951 and the zero reference levels of the International Organization for Standardization (ISO) of 1964.

Table II shows the comparison between the various incidence studies reviewed. Each study is listed according to its order in the manuscript. 
TABLE II

COMPARISON OF DATA ON HEARING LOSS INCIDENCE IN MENTAL RETARDATES

\begin{tabular}{|c|c|c|c|c|c|}
\hline Study & $\begin{array}{c}\text { Subjects } \\
\text { N }\end{array}$ & Sample & $\begin{array}{l}\text { Definition of } \\
\text { Hearing Loss }\end{array}$ & $\begin{array}{c}\text { Frequencies } \\
\text { Tested }\end{array}$ & Incidence \\
\hline $\begin{array}{l}\text { Birch- } \\
\text { Matthews } \\
(1951)\end{array}$ & 247 & $\begin{array}{l}\text { Institutionalized } \\
\text { mental retardates at } \\
\text { Polk State School, } \\
\text { Polk, Penn. }\end{array}$ & $\begin{array}{l}\text { A loss of } 20 \mathrm{~dB} \text { ASA } \\
\text { in one or more freq. } \\
\text { in either ear. }\end{array}$ & $512-8192 \mathrm{~Hz}$ & $55 \%$ \\
\hline $\begin{array}{l}\text { Foale- } \\
\text { Patterson } \\
(1954)\end{array}$ & 100 & $\begin{array}{l}\text { Institutionalized } \\
\text { mental retardates at } \\
\text { Lennox Castle Inst. } \\
\text { Scotland. }\end{array}$ & $\begin{array}{l}\text { A loss of } 20 \mathrm{~dB} A \mathrm{ASA} \\
\text { in one or more freq. } \\
\text { in either ear. }\end{array}$ & $250-4000 \mathrm{~Hz}$ & $33 \%$ \\
\hline \multirow[t]{2}{*}{$\begin{array}{l}\text { Siegenthaler- } \\
\text { Krzywicki } \\
\text { (1959) }\end{array}$} & 638 & $\begin{array}{l}\text { Institutionalized } \\
\text { mental retardates at } \\
\text { Laurelton, Penn. }\end{array}$ & $\begin{array}{l}\text { A loss of } 20 \mathrm{~dB} \text { ASA } \\
\text { in one or more freq. } \\
\text { in either ear. }\end{array}$ & $250-4000 \mathrm{~Hz}$ & $32 \%$ \\
\hline & 396 & $\begin{array}{l}\text { Institutionalized } \\
\text { educable mental } \\
\text { retardates at } \\
\text { Laurelton, Penn. }\end{array}$ & Same as above & Same as above & $17 \%$ \\
\hline $\begin{array}{l}\text { Lloyd- } \\
\text { Reid } \\
(1967)\end{array}$ & 638 & $\begin{array}{l}\text { Institutionalized } \\
\text { mental retardates at } \\
\text { Parsons Training Center, } \\
\text { Parsons, Kansas. }\end{array}$ & $\begin{array}{l}\text { A loss of } 20 \mathrm{~dB} \text { ISO } \\
\text { in one or more freq. } \\
\text { in either ear. }\end{array}$ & $500-4000 \mathrm{~Hz}$ & $19 \%$ \\
\hline
\end{tabular}




\begin{tabular}{|c|c|c|c|c|c|}
\hline Study & $\begin{array}{l}\text { Subjects } \\
\text { N }\end{array}$ & Sample & $\begin{array}{l}\text { Definition of } \\
\text { Hearing Loss }\end{array}$ & $\begin{array}{c}\text { Frequencies } \\
\text { Tested }\end{array}$ & Incidence \\
\hline $\begin{array}{l}\text { Marshall } \\
(1967)\end{array}$ & 200 & $\begin{array}{l}\text { Survey of mentally } \\
\text { retarded children seen } \\
\text { at Multi-Discipline } \\
\text { Clinic, University of } \\
\text { Oregon Medical School }\end{array}$ & $\begin{array}{l}\text { A loss of } 20 \mathrm{~dB} \text { ISO } \\
\text { in one or more freq. } \\
\text { in either ear. }\end{array}$ & $500-8000 \mathrm{~Hz}$ & $17 \%$ \\
\hline $\begin{array}{l}\text { Johnston- } \\
\text { Farrell } \\
(1954)\end{array}$ & 247 & $\begin{array}{l}\text { Institutionalized } \\
\text { mental retardates at } \\
\text { Fernald State School } \\
\text { in Massachusetts. }\end{array}$ & $\begin{array}{l}\text { A loss of } 20 \mathrm{~dB} \text { ASA } \\
\text { in two or more freq. } \\
\text { in either ear. }\end{array}$ & $250-6000 \mathrm{~Hz}$ & $24 \%$ \\
\hline $\begin{array}{l}\text { Schlanger- } \\
\text { Gottsleben } \\
(1956)\end{array}$ & 498 & $\begin{array}{l}\text { Institutionalized } \\
\text { mental retardates at } \\
\text { The Training School, } \\
\text { Vineland, N. J. }\end{array}$ & $\begin{array}{l}\text { A loss of } 20 \mathrm{~dB} \text { ASA } \\
\text { in two or more freq. } \\
\text { in either ear. }\end{array}$ & $125-12000 \mathrm{~Hz}$ & $25.7 \%$ \\
\hline $\begin{array}{l}\text { Rigrodsky } \\
\text { et al. } \\
(1961)\end{array}$ & 325 & $\begin{array}{l}\text { Institutionalized } \\
\text { mental retardates at } \\
\text { The Training School, } \\
\text { Vineland, N. J. }\end{array}$ & $\begin{array}{l}\text { A loss of } 20 \mathrm{~dB} \text { ASA } \\
\text { in two or more freq. } \\
\text { in either ear. }\end{array}$ & $250-8000 \mathrm{~Hz}$ & $25 \%$ \\
\hline $\begin{array}{l}\text { Webb } \\
\text { et al. } \\
(1964)\end{array}$ & 369 & $\begin{array}{l}\text { Institutionalized } \\
\text { mental retardates at } \\
\text { Mt. Pleasant St. Home } \\
\text { and Tr. School, Mich. }\end{array}$ & $\begin{array}{l}\text { A loss of } 20 \mathrm{~dB} \text { ASA } \\
\text { in two or more freq. } \\
\text { in either ear. }\end{array}$ & $500-2000 \mathrm{~Hz}$ & $25 \%$ \\
\hline
\end{tabular}




\begin{tabular}{|c|c|c|c|c|c|}
\hline Study & $\begin{array}{c}\text { Subjects } \\
\mathrm{N}\end{array}$ & Sample & $\begin{array}{l}\text { Definition of } \\
\text { Hearing Loss }\end{array}$ & $\begin{array}{l}\text { Frequencies } \\
\text { Tested }\end{array}$ & Incidence \\
\hline $\begin{array}{l}\text { Webb } \\
\text { et al. } \\
(1964)\end{array}$ & 1093 & $\begin{array}{l}\text { Institutionalized } \\
\text { mental retardates at } \\
\text { Mt. Pleasant St. Home } \\
\text { and Tr. School, Mich. }\end{array}$ & $\begin{array}{l}\text { Failure to give two } \\
\text { observable responses } \\
\text { to } 20 \mathrm{~dB} \text { ASA live } \\
\text { voice sounds. }\end{array}$ & $\begin{array}{l}\text { Sound field } \\
\text { Speech } \\
\text { audiometry } \\
\text { Live voice }\end{array}$ & $24 \%$ \\
\hline $\begin{array}{l}\text { Kodman } \\
\text { et al. } \\
(1958)\end{array}$ & 208 & $\begin{array}{l}\text { Institutionalized } \\
\text { mental retardates at } \\
\text { The Kentucky Tr. Hm. , } \\
\text { Frankfort, Kentucky }\end{array}$ & $\begin{array}{l}\text { A loss of } 30 \mathrm{~dB} \text { ASA } \\
\text { in one of more freq. } \\
\text { in either ear. }\end{array}$ & $250-8000 \mathrm{~Hz}$ & $20.4 \%$ \\
\hline $\begin{array}{l}\text { Schlanger- } \\
\text { Gottsleben } \\
(1956)\end{array}$ & 498 & $\begin{array}{l}\text { Institutionalized } \\
\text { mental retardates at } \\
\text { The Training School, } \\
\text { Vineland, N. J. }\end{array}$ & $\begin{array}{l}\text { A loss of } 30 \mathrm{~dB} \text { ASA } \\
\text { in one or more freq. } \\
\text { in either ear. }\end{array}$ & $125-12000 \mathrm{~Hz}$ & $43 \%$ \\
\hline $\begin{array}{l}\text { Rittmanic } \\
\text { (1959) }\end{array}$ & 495 & $\begin{array}{l}\text { Institutionalized } \\
\text { mental retardates at } \\
\text { Dixon State School, } \\
\text { Dixon, Illinois }\end{array}$ & $\begin{array}{l}\text { A loss of } 15 \mathrm{~dB} \text { ASA } \\
\text { in two or more freq. } \\
\text { in either ear. }\end{array}$ & $250-8000 \mathrm{~Hz}$ & $40.5 \%$ \\
\hline $\begin{array}{l}\text { Schlanger } \\
(1961)\end{array}$ & 199 & $\begin{array}{l}\text { Institutionalized } \\
\text { mental retardates at } \\
\text { St. Mary's Training } \\
\text { School, N. J. }\end{array}$ & $\begin{array}{l}\text { A loss of } 30 \mathrm{~dB} \text { ASA } \\
\text { in two or more freq. } \\
\text { in either ear. }\end{array}$ & $500-4000 \mathrm{~Hz}$ & $42 \%$ \\
\hline
\end{tabular}




\begin{tabular}{|c|c|c|c|c|c|}
\hline Study & $\begin{array}{c}\text { Subjects } \\
\mathrm{N}\end{array}$ & Sample & $\begin{array}{l}\text { Definition of } \\
\text { Hearing Loss }\end{array}$ & $\begin{array}{c}\text { Frequencies } \\
\text { Tested }\end{array}$ & Incidence \\
\hline $\begin{array}{l}\text { Anderson } \\
(1964)\end{array}$ & 2235 & $\begin{array}{l}\text { Special Achievement } \\
\text { Classes (educable } \\
\text { mentally retarded) } \\
\text { State of Oregon. }\end{array}$ & $\begin{array}{l}\text { A loss of } 20 \mathrm{~dB} \text { ASA } \\
\text { in three or more freq. } \\
\text { in either ear. }\end{array}$ & $500-6000 \mathrm{~Hz}$ & $17 \%$ \\
\hline $\begin{array}{l}\text { Holmes- } \\
\text { Peletier } \\
(1966)\end{array}$ & 824 & $\begin{array}{l}\text { Institutionalized } \\
\text { mental retardates at } \\
\text { Pineland Hospital and } \\
\text { Training Center, } \\
\text { Pownal, Maine. }\end{array}$ & $\begin{array}{l}\text { Average threshold of } \\
15 \mathrm{~dB} \text { ISO in sp. freq. } \\
\text { in either ear. }\end{array}$ & $500-8000 \mathrm{~Hz}$ & $17 \%$ \\
\hline $\begin{array}{l}\text { Fulton- } \\
\text { Griffin } \\
(1967)\end{array}$ & 2290 & $\begin{array}{l}\text { Institutionalized } \\
\text { mental retardates at } \\
\text { Fort Wayne State } \\
\text { Hospital and Training } \\
\text { Center, Fort Wayne, Ind. }\end{array}$ & $\begin{array}{l}\text { Average threshold of } \\
25 \mathrm{~dB} \text { ISO of the five } \\
\text { frequencies tested. }\end{array}$ & $500-8000 \mathrm{~Hz}$ & $27.4 \%$ \\
\hline
\end{tabular}




\section{STATEMENT OF THE PROBLEM}

The speech and hearing clinician in the public schools is very likely to be presented with communication problems of the mentally retarded at some time during his career. The sizeable number of speech and hearing defective children in the educable retarded class room (Department of Research and Manuscripts, Portland, Oregon, 1963; Young, 1965; Marshall, 1967) alone constitute a challenge to a speech and hearing clinician's training and experience.

Since the numbers of retardates with communication problems are considerable, the Vancouver School District 37 Speech and Hearing Department has directed increased attention toward the special education classrooms in recent years. Time allotments, case loads, and school assignments were adjusted to allow speech and hearing screening of the special education classrooms.

Although speech and language screening of the mentally retarded does not present particular difficulty to the speech clinician, differential hearing diagnosis of the retarded often requires considerable time, training, and experience. With increasing numbers of communicatively handicapped school children confronting the public 
school speech and hearing clinician each year, the time available for the hearing problems of the retarded has been minimal. Consequently, many of the hearing impaired children in the special education classrooms of Vancouver School District 37 have gone undiagnosed and untreated.

The current study on the incidence of hearing loss in the special education classrooms of Vancouver School District 37 was prompted by concern over the number of inadequately served mental retardates with hearing impairment. In order to more efficiently treat this problem, it was felt that a comprehensive investigation into the incidence and types of hearing loss of this population would provide a basis for program design.

It is the intent of this survey to determine, by audiological testing, the answers to the following questions:

1. What is the incidence of hearing loss of the special education classrooms of Vancouver School District 37?

2. Is the incidence of hearing loss related to age level or measured intelligence level?

3. What are the types of hearing loss found in the special education classrooms of Vancouver School District 37 ?

4. Are the representative types of hearing loss related to age level? 


\section{CHAPTER IV}

\section{METHOD}

\section{SUBJECTS}

Two hundred forty mentally retarded children, consisting of 148 boys and 92 girls, constitute the enrollment of the Vancouver School District 37 special education classrooms. None of the subjects was found to be untestable; however, 28 were absent on repeated test dates and consequently were not included in the survey. Thus, the total sample for the different statistical treatments was 212 subjects. Data on those subjects included in the survey encompassed the following items.

\section{Intelligence}

The children presented in this survey range in IQ from 30 to 81 on the Revised Stanford-Binet. This range encompasses MI Levels I through.IV, "borderline," to "severe" retardation. Lloyd and Frisina (1965) have stated that levels below approximately $40 \mathrm{IQ}$ are most challenging for the clinical audiologist, and Spradlin (1967) stated that audiologists have been able to accomplish pure tone testing with most children with IQs of 40 or more, which is about the 
lower limits of the moderate range of retardation. The representation of four levels of retardation is fortunate in that comparison between levels is easily accomplished.

Recorded IQs available for 205 of the 212 subjects ranged from 30 to 81 , with a mean of 60.2 . The remaining 7 were unrecorded except in terms of general range or medical diagnosis. Four of the se subjects had unspecified IQs but had been diagnosed as "moderate" in retardation. Three subjects had a medical diagnosis of "severe" retardation. (See Figure 1.)

\section{Chronological Age}

$\mathrm{CA}$ is of particular importance in a survey of hearing loss incidence because it gives an additional basis for comparison. The age range in the special education classrooms in Vancouver School Dis trict 37 is from age 6 through 19 years. The vocational training program in District 37 usually won't admit a child if he will be 20 years old before graduation from the program; however, students over 18 years of age represent an exception. The 212 subjects included in this study ranged from 6.5 years to 18.25 years with a mean CA of 12.8 years. (See Figure 2.)

\section{Physiologic and Sensory Factors}

Twenty-four subjects in this survey were additionally handicapped with varying degrees of neuro-muscular involvement, brain 


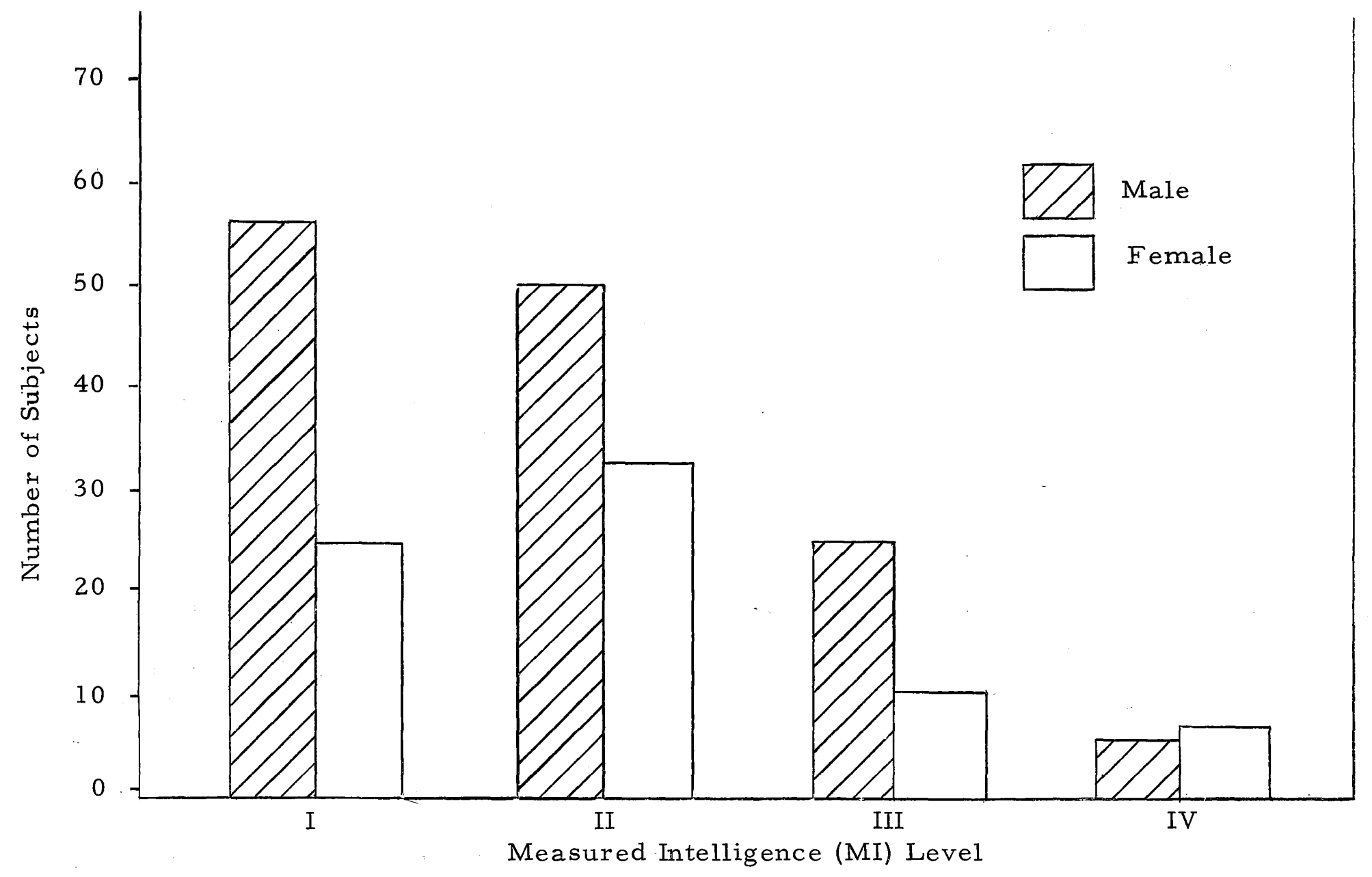

Figure 1. Total number of male and female subjects at each MI level. 


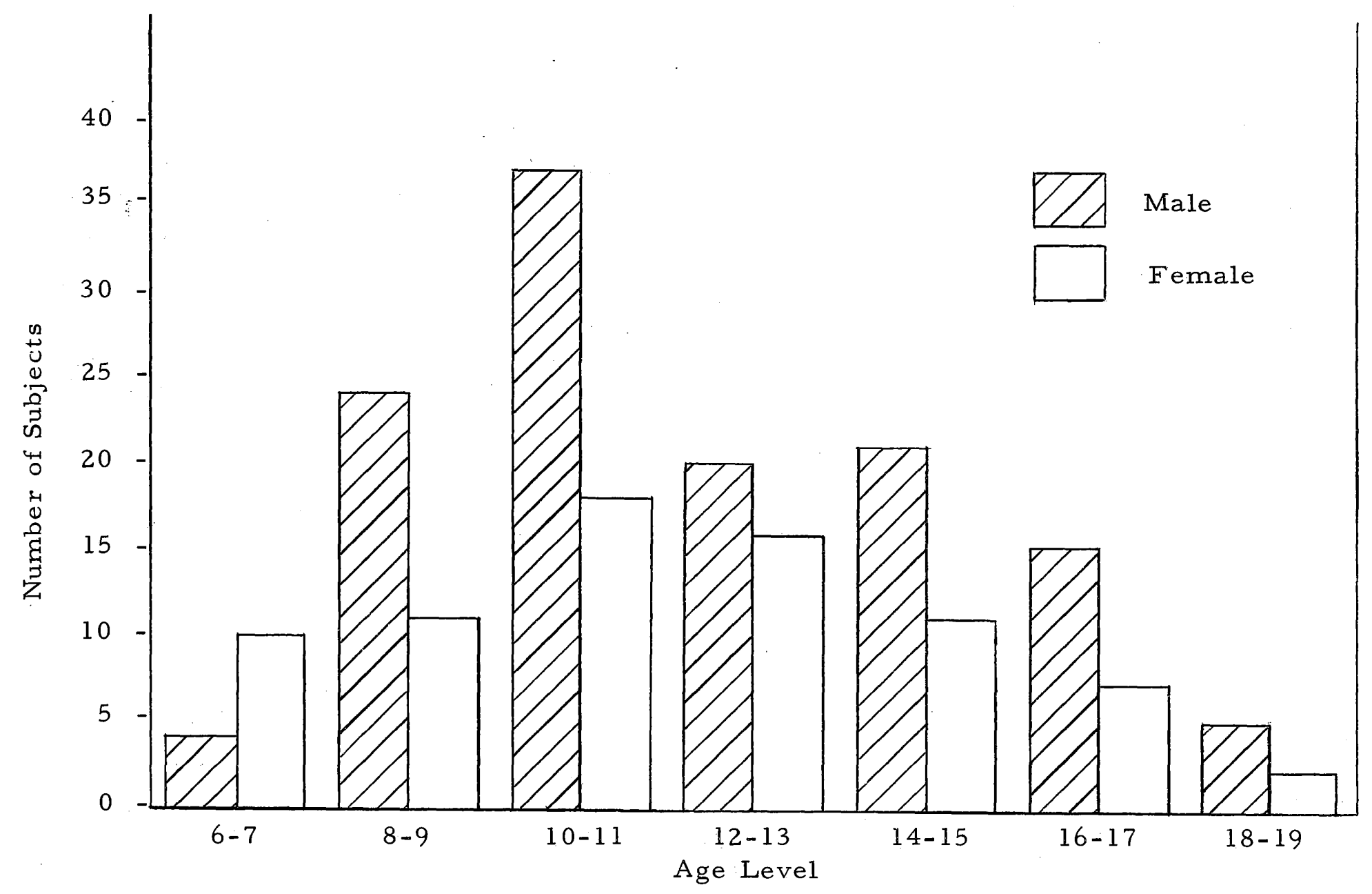

Figure 2. Total number of male and female subjects at each age level. 
damage, or other physical impairments. which presented special considerations in the testing procedures. Regardless of physical impairment, all 24 subjects in this group were found to be testable, although procedures for several were altered considerably from conventional audiometric techniques. Children with colds, running ears, or other characteristics which, on superficial examination, were likely to impair hearing level, were deferred until later dates. The sensory factor of hearing acuity was not regarded in this survey. All children enrolled in Vancouver District special education classrooms.were included and no regard was given to past known hearing losses, hearing aids, etc.

\section{TEST ROOM AND EQUIPMENT}

This survey of hearing loss in special education classrooms was conducted at seven different locations throughout the school district. Although there were a total of 12 different locations, five were eliminated, and the children from those areas were tested in a sound booth at the Speech and Hearing Department, Vancouver School District 37. All tests were conducted during normal school hours. Those eight locations used in the survey offered adequate, isolated rooms in which tests were to be administered. Each room was equipped with at least two chairs for examiner and subjects, a table for testing equipment, adequate light, and easy access. The 
minimum requirements for an "adequate" testing environment were maintained along the description of a testing room by $\mathrm{O}^{\prime} \mathrm{Neill}$ and Oyer (1966, p. 59). This implies that the room should be as isolated as possible from outside walls, busy hallways and rooms, elevators, and heating and plumbing noises. If the noise level in a test room is so high that a person with normal hearing cannot hear normal audiometric sounds (hearing loss dial set at $15 \mathrm{~dB}$. ASA), or if the reading on a sound-level meter is greater than $50 \mathrm{~dB}$ ASA (1951), using the C scale reading, the room is not considered "adequate."

Seven of the eight locations offered test rooms which met the above standards for $15 \mathrm{~dB}$ on a normal hearing individual, besides also meeting the physical environment requirements. The eighth room was the sound booth at the Speech and Hearing Department of the Vancouver School District 37. The ambient noise level in this sound booth was measured repeatedly: with a General Radio Company Type 2203 sound-level meter and was found to vary within a range of 33 to $49 \mathrm{~dB}$ SPL on the C scale (ASA, 1951).

All testing was administered with a recently calibrated Beltone 12D portable audiometer. This audiometer was calibrated prior to the initiation of the survey and was checked for appropriate calibration at approximately midway in testing; however, no further calibration was required. 


\section{SELECTION OF STIMULI}

All tests were administered in this survey at ISO (1964) refer ence levels and included the frequencies 500 through $4000 \mathrm{~Hz}$, deliv-. ered by both air-and bone-conduction. These frequencies were selected because: (1) they represent a valid sample of the normal test frequency range to adequately indicate communicatively significant hearing loss and (2) they require only four frequencies per ear to be tested, resulting in the examiner's ability to markedly expedite the test duration.

\section{CONDITIONING AND REINFORCEMENT}

Most of the higher level (MI levels I, II, and III) subjects in this survey did not need tangible reinforcement for adequate audiological assessment. Most of the Level IV and many Level III retardates, however, required the use of operant audiometric techniques to gain a reliable hearing examination. The operant procedures used have been described in Lloyd, Spradlin, and Reid (1968), Bricker and Bricker (1969), and Stewart (1970).

Social reinforcement was administered to all subjects on a random basis. These social reinforcements consisted of the examiner's exclamations of "Fine," "Good," "Excellent," etc., accompanied by a smile and/or nod. 
When tangible reinforcement was used, it was administered on a $100 \%$ schedule, after Horowitz (1963), who reported that combined tangible and verbal (social) reinforcement of vocal responses resulted in the greatest resistance to extinction and that continuous reinforcement was much more effective than partial $(50 \%)$ reinforcement in achieving stimulus control.

Each child who was administered tangible reinforcement was allowed to choose one of nine reinforcers, each in a separate cup of a muffin tin. The specific reinforcers were a combination of nutrients (halved M\&M candies, Cocoa Puffs, Crispy Critters, and halved chocolate chips) and trinkets (small plastic trucks, dogs, dolls, feet, teeth, paper stickers, and flags). The child was allowed to select one each time he responded appropriately to the tonal stimulus.

\section{PROCEDURES}

Each child was subjected to a single pure tone threshold examination. The children from each classroom were tested in a random order.

Two examiners were utilized for this survey. Each examiner was a practicing speech and hearing clinician and had past clinical experience in testing the hearing of mentally retarded children. In order to ascertain reliability, the examiners employed a test-retest 
procedure in which ten children, selected at random, were crosschecked (inter-tester) for threshold levels. Using the Pearson Product-Moment Correlation for each frequency tested, the two tests correlated as follows: $500 \mathrm{~Hz}$ at . 91; $1000 \mathrm{~Hz}$ at . 91;2000 Hz at. 95; $4000 \mathrm{~Hz}$ at. 90. Intra-tester reliability checks also were carried out on ten randomly selected children. Each examiner was required to retest ten children for whom he had no knowledge of previous test results. Pearson Product-Moment Correlations also were carried out for the intra-tester cross-checks, and the results are as follows: Examiner I, $500 \mathrm{~Hz}$ at . 97; $1000 \mathrm{~Hz}$ at $.93 ; 2000 \mathrm{~Hz}$ at .92; and $4000 \mathrm{~Hz}$ at. 87; Examiner II, $500 \mathrm{~Hz}$ at .97; $1000 \mathrm{~Hz}$ at .97; $2000 \mathrm{~Hz}$ at . 98; and $4000 \mathrm{~Hz}$ at . 87.

\section{Criteria for Hearing Loss}

The criteria used in this survey were designed not only to most efficiently determine those who have a hearing loss, but also to correspond to the Washington State Crippled Children's Manual (revised, 1966) on medical eligibility for hearing loss. The latter was employed to insure that those subjects found having a hearing loss could receive prompt and inexpensive otologic treatment. The criterion for hearing loss in this survey was a loss of $20 \mathrm{~dB}$ or more in two or more frequencies in either ear. 
Air-Conduction Tests

All 212 subjects tested in this survey were administered an air-conduction threshold examination at the previously described test frequencies. Although there is great variability in testing techniques reported in the literature, the current examiners adhered to an exactly prescribed outline of the test procedure. It was felt that adherence to this procedural outline is one factor which produced such a high correlation on the inter-tester reliability checks.

Through previous clinical experience and the review of previous research, the revised technique of Newhart and Reger (1945; revised, 1956) was chosen by the examiners for this survey. A detailed account of this procedure is given in O'Neill and Oyer (1966, p. 54):

. . . testing (should) be commenced at $1024 \mathrm{~Hz}$. Then the lower or higher frequencies could be followed by a recheck of the threshold obtained at $1024 \mathrm{~Hz}$. Also, the tone should be first presented at an intensity level of $30 \mathrm{~dB}$ above normal threshold level, that is, a hearing loss dial setting of either $30 \mathrm{~dB}$ or $45 \mathrm{~dB}$. If the sound is not heard at this level, it was to be increased at $20 \mathrm{~dB}$ steps until the subject responded. Once the first response was made, the tone stimulus was decreased in $10 \mathrm{~dB}$ steps until the subject indicated that he no longer heard the tone. From this point, the tone was increased in $5 \mathrm{~dB}$ steps until a response was obtained and then decreased in $5 \mathrm{~dB}$ steps until no response was obtained. This bracketing process was continued until three definite threshold measurements were made.

O'Neill and Oyer also suggest that the tones should not be presented in a rhythmical sequence and that the examiner take notice of the reaction time of the individual being tested. 
A signal duration of two seconds was used to help coordinate inter-tester and intra-tester reliability and also to achieve the most accurate threshold possible. Two seconds'duration was selected after consulting research reports on perceived threshold. Goldstein and Kramer (1960) noted that the threshold values for pure tones should not be expected to decrease significantly for signals of longer than $2000 \mathrm{msec}(2 \mathrm{~seconds})$.

\section{Bone-Conduction Tests}

Although reliability of bone-conduction testing and its various procedures often have been accompanied by considerable confusion, the investigators in this survey felt that the diagnostic implications afforded by bone-conduction were too great to disregard. While all the 212 subjects received air-conduction threshold examinations, only those subjects who revealed a 20 dB loss in two or more frequencies in either ear were administered bone-conduction examinations. This criterion corresponds to the Washington State Crippled Children's Manual (revised, 1966) on medical eligibility for hearing loss.

The audiometric technique for testing bone-conduction was the same as that used for air-conduction (Newhart and Reger, 1945; revised, 1956); however, certain variables were present which were taken into consideration. 
The placement of the bone-conduction oscillator has been a source of concern with several authors in the literature. Hirsh (1952) indicated that it would be better to place the bone-conduction oscillator on the midline of the forehead rather than on the mastoid process. Studebaker (1962) stated that there is less inter-subject variability when using the forehead midline placement rather than the mastoid placement. Naughton (1961) mentions that there is less difference as to the position along the midline of the forehead as there is difference in position along the mastoid process.

While the research appears to indicate that the forehead placement is often preferred over mastoid placement, Naughton (1961) also has revealed that it takes more power to drive the same amount of sound energy to the cochlea from the forehead; consequently, the equipment should be calibrated appropriately. O'Neill and Oyer (1966) recommend the mastoid position in their description of procedures for bone-conduction testing. Equipment availability was a limitation of the present investigation, and since the Beltone $12 \mathrm{D}$ audiometer is calibrated for mastoid placement of the oscillator, this position was used in this study.

Masking for Air-and Bone-Conduction

White noise masking. was introduced into the contralateral ear during air-conduction when a difference of $40 \mathrm{~dB}$ or more between 
ears was observed. This was to insure that the ear under test was actually the one being tested. It was felt that a masking level of at least $50 \mathrm{~dB}$ above the threshold for the better ear, or the ear being masked, was sufficient (O'Neill and Oyer, 1966).

White noise also was introduced into the contralateral ear during bone-conduction testing; however, masking was used to a greater extent than in air-conduction. Hirsh (1952) mentions that intra-aural attenuation for bone-conduction is only $10 \mathrm{~dB}$ rather than $50 \mathrm{~dB}$ as in air-conduction. Since the problem of lateralization is very pronounced in bone-conduction, masking was used each time a bone-conduction test was administered. Care was used, however, not to mask out the ear being tested. The problem of lateralization also can work in reverse; that is, the masking sound may: be so loud that it will be heard in the contralateral ear, the ear being tested.

Masking was presented to the subjects by turning on the masking generator before the ear phones were placed on the head. This procedure allowed the subject to adapt more readily and become less distracted by the masking. white noise.

\section{Operant Procedures}

Forty-four of the subjects in the survey were deemed difficultto-test and were deferred from the conventional conditioning audiometry as described above. Most of these DTT (difficult-to-test) 
patients were from MI Levels III and IV.

The response class of vocalizing responses has been shown by Stewart (1970) to be an effective and practical response mode to pure tone stimuli in a sample of moderately and severely retarded children. Stewart also has shown that the transfer of vocalizations to pure tone stimuli is achieved by matching a loud pure tone to the examiner's vocalizations until the pure tones became an $S^{D}$ for the subject's vocalization. The procedures followed in testing the 44 DTT patients were closely related to those outlined by Stewart:

1. The examiner vocalized /a/ and indicated that the child was to follow suit. The child was immediately reinforced for his vocalization; however, he was reinforced for only those vocalizations which were felt to be a result of the examiner's vocalization. None of the children needed more than ten trials to gain stimulus control over their vocalizations.

2. The examiner then presented a loud tone through the ear phone four seconds prior to each of the examiner's stimulus vocalizations, and continued through the superimposed vocalization for another two seconds, and then terminated both simultaneously. This contingency was repeated as necessary to achieve transfer of the $S^{D}$ properties of the examiner's vocalizations to the pure tones. The examiner's vocalizations were omitted from this contingency just as soon as the child responded to the pure tones. 
3. The threshold examination was then carried out with the child's response vocalizations under stimulus control of the pure tone stimuli. 


\section{CHAPTER V}

\section{RESULTS}

The current survey has revealed that, of the 212 subjects tested in the special education classrooms of the Vancouver School District, 38 had hearing losses of $20 \mathrm{~dB}$ or more in two or more frequencies in either ear. This number established an incidence of 17. $9 \%$ for this population. The audiometric data on each of the 212 subjects were analyzed according to MI levels, age levels, sex, and type of loss.

\section{HEARING LOSS IN RELATION TO MI LEVEL}

The percentage of subjects with hearing loss at each MI level, utilizing the $20 \mathrm{~dB}$ criterion, is graphically displayed in Figure 3. The data indicate that, in general, the incidence of hearing loss is greater among the more severely retarded (MI levels III and IV) than among the less retarded (MI levels I and II). Fourteen per cent of the MI level I subjects and $13 \%$ of the MI level II subjects revealed a hearing loss; however, $24 \%$ of the MI level III subjects and $45 \%$ of the MI level IV subjects had losses. 


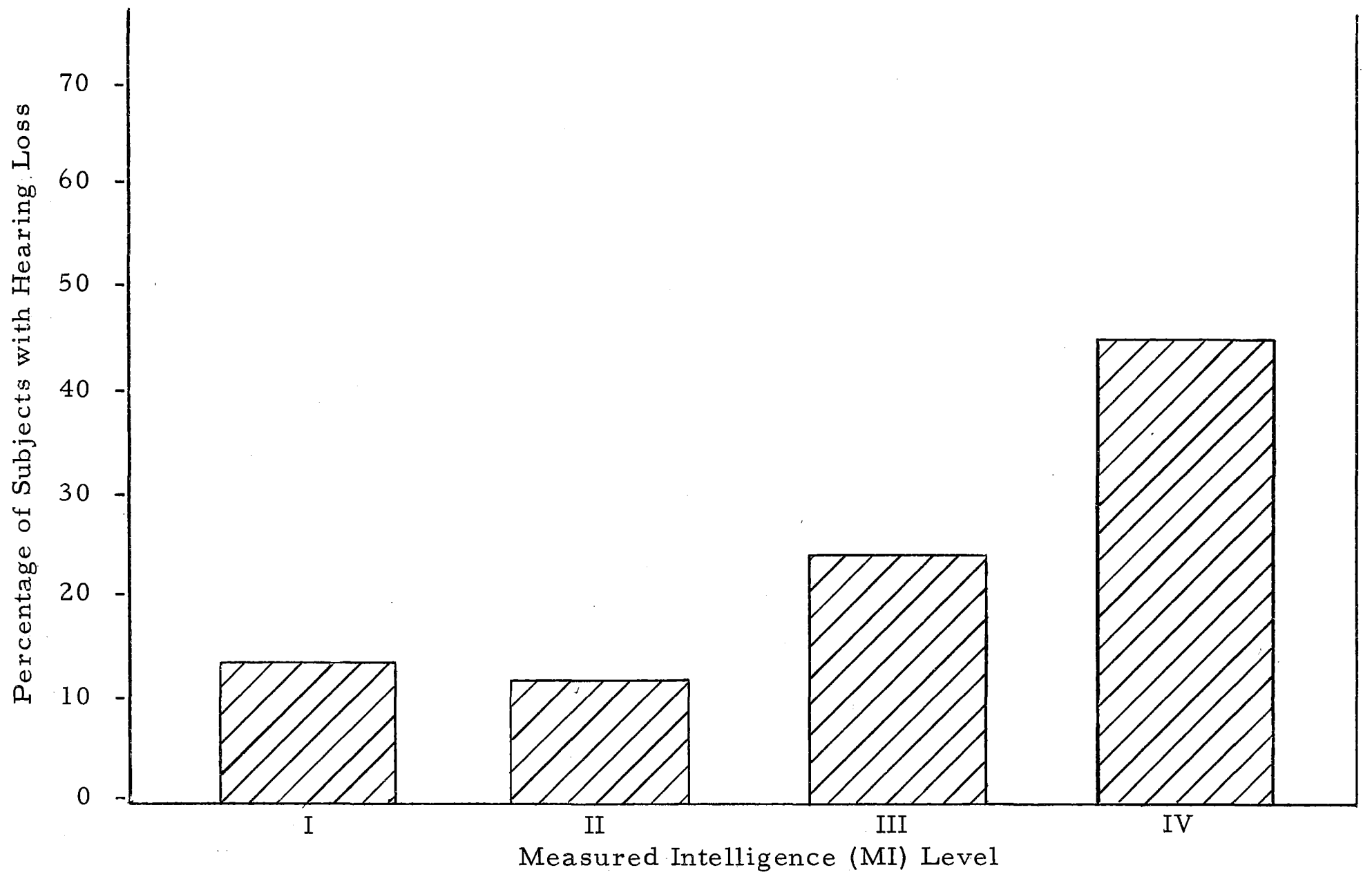

Figure 3. Percentage of subjects with hearing loss at each MI level.

$\stackrel{\mapsto}{\mapsto}$ 
II. HEARING LOSS IN RELATION TO AGE LEVEL

The percentage of subjects with hearing loss at each age level, 6-7 years through 18-19 years, is shown in Figure 4. The audiometric data depict a general trend toward a decrease in hearing loss incidence with increasing age.

\section{HEARING LOSS IN RELATION TO SEX}

Considering the total number of 38 children with hearing loss, a slightly higher percentage of males (53\%) than females $(47 \%)$ was evident. For higher level retardates (MI levels I and II), 32\% of those with hearing losses were male and $26 \%$ female; however, for lower level retardates (MI levels III and IV), the percentage of those with hearing loss was the same for both sexes, $21 \%$. The percentage of male and female subjects with hearing loss was analyzed by MI level and age level and is displayed in Figures 5 and 6.

\section{HEARING LOSS IN RELATION TO TYPE}

Figure 7 is a graphic representation of the hearing loss types at each age level. Three categories of hearing loss types are displayed: conductive, sensori-neural, and mixed sensori-neural// conductive. A primarily conductive impairment was defined as a significant air-bone gap with essentially normal bone-conduction 


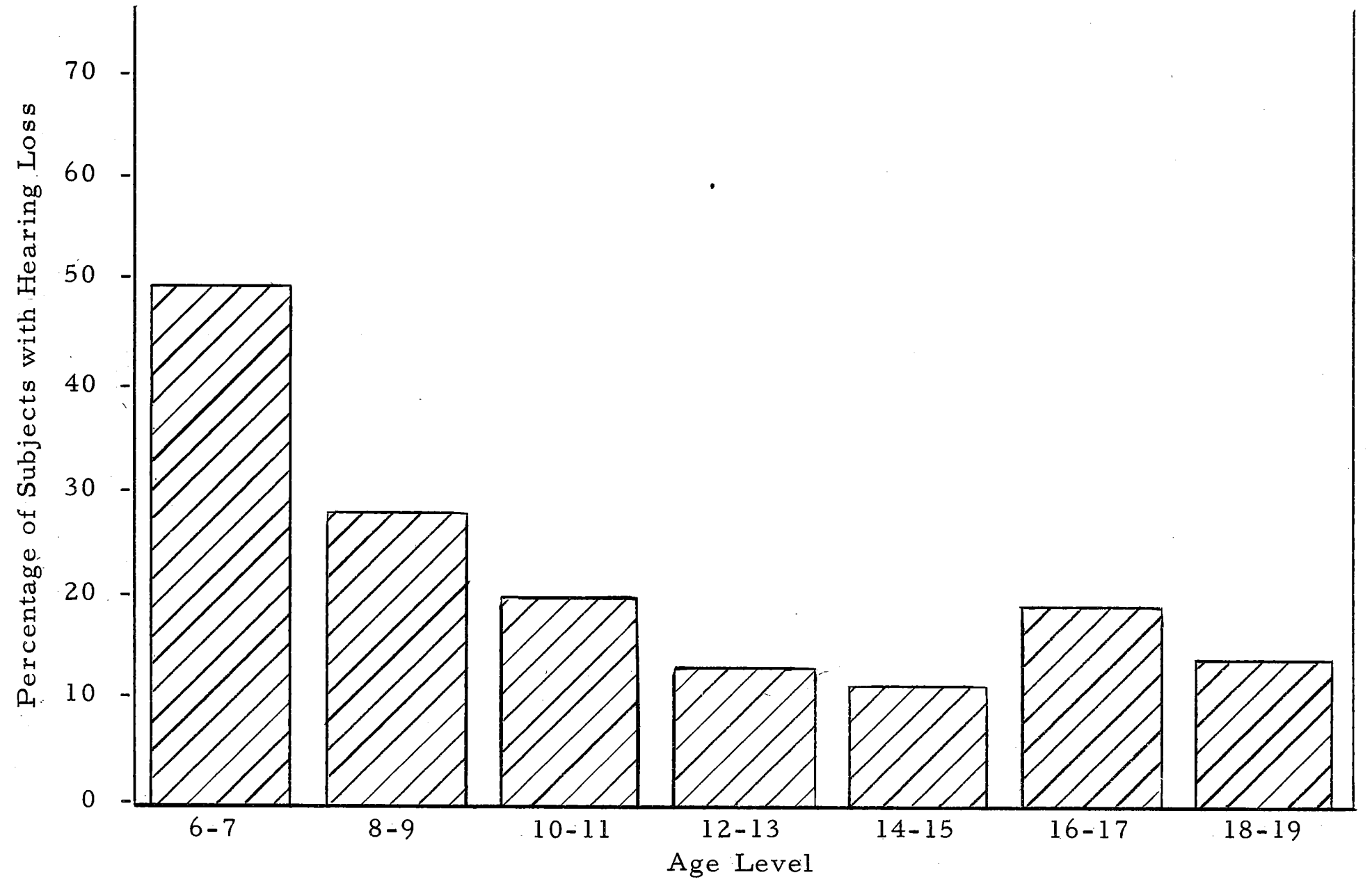

Figure 4. Percentage of subjects with hearing loss at each age level. 


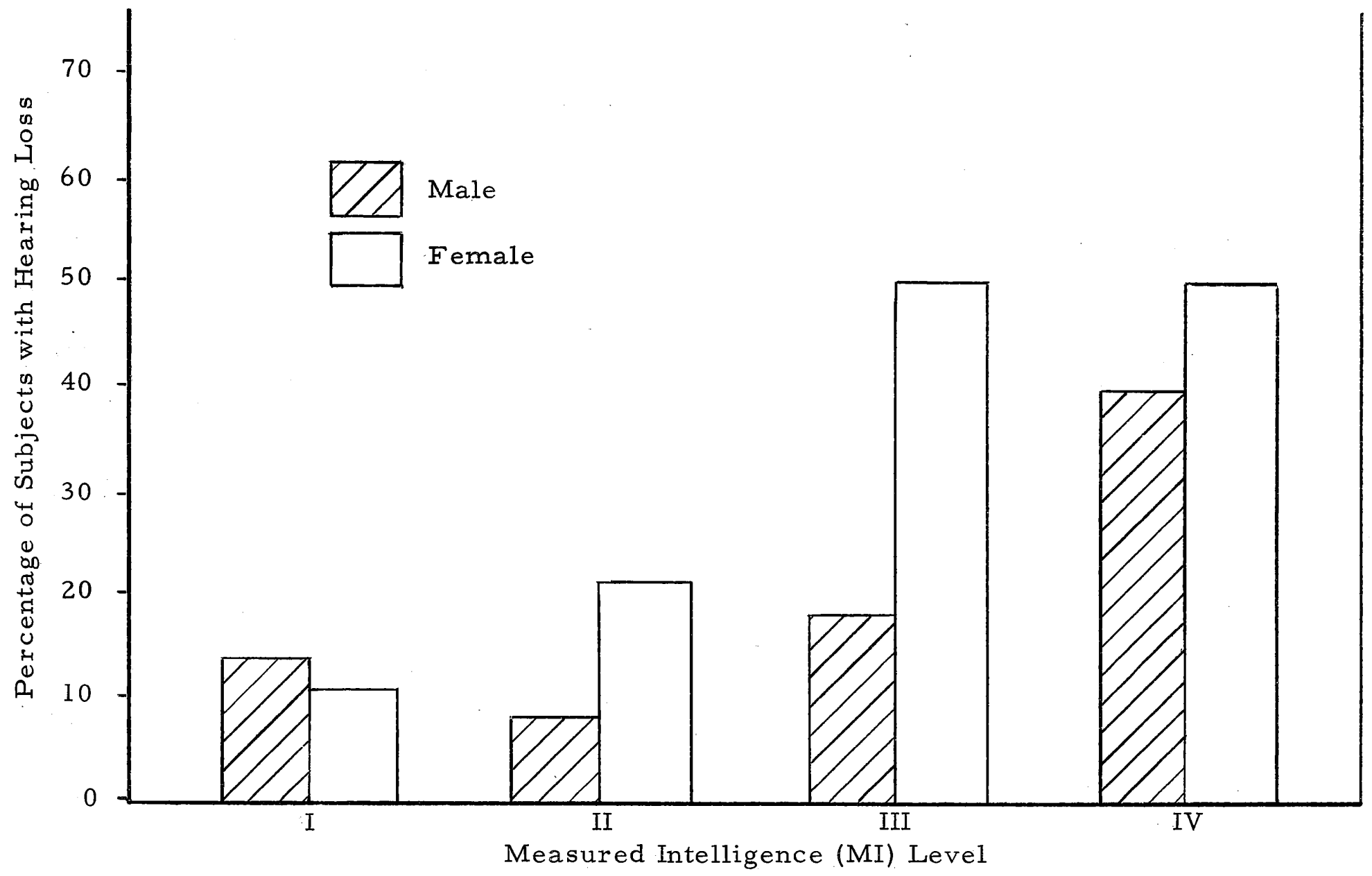

Figure 5. Percentage of male and female subjects with hearing los at each MI level. 


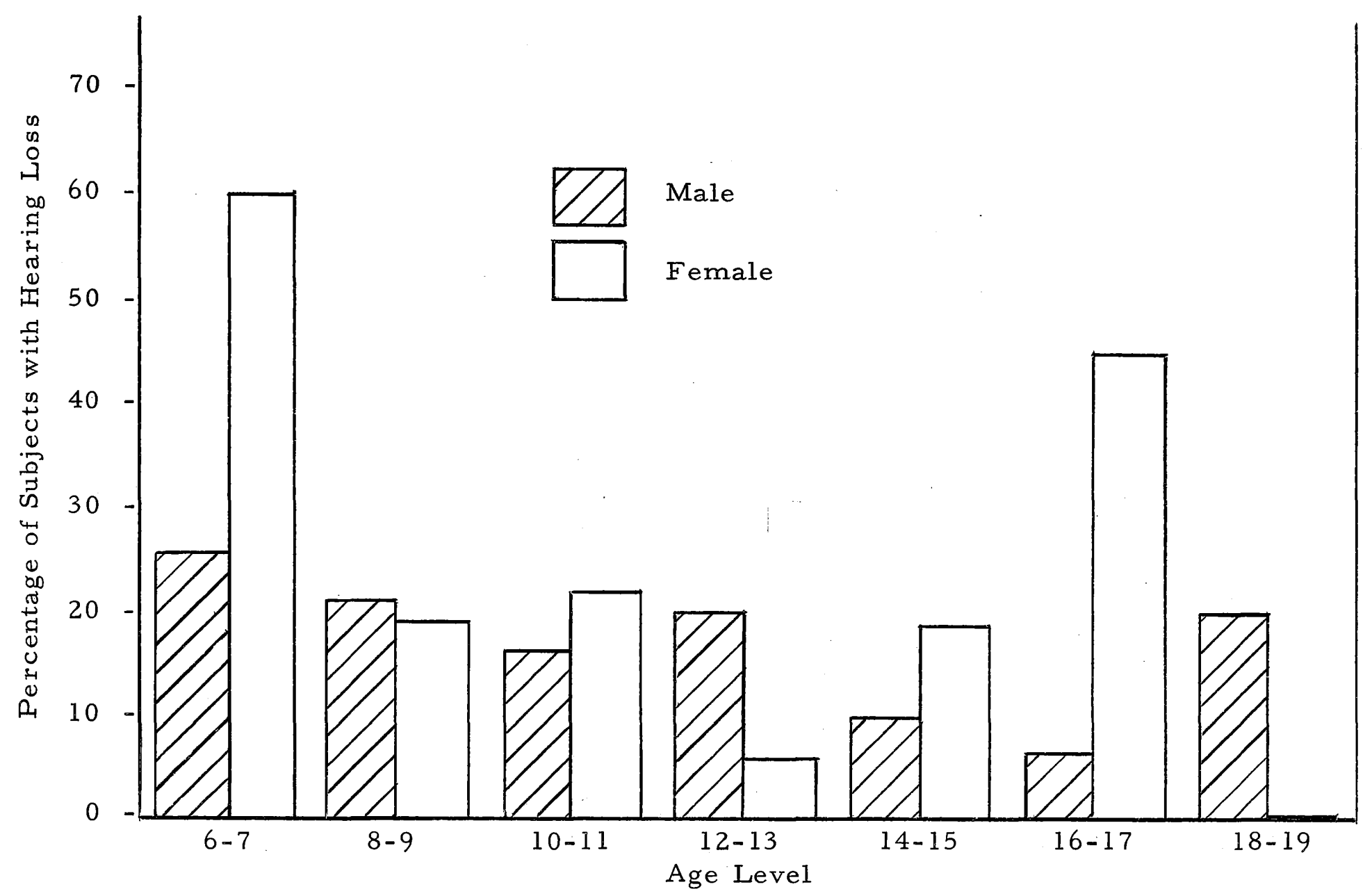

Figure 6. Percentage of male and female subjects with hearing loss at each age level. 


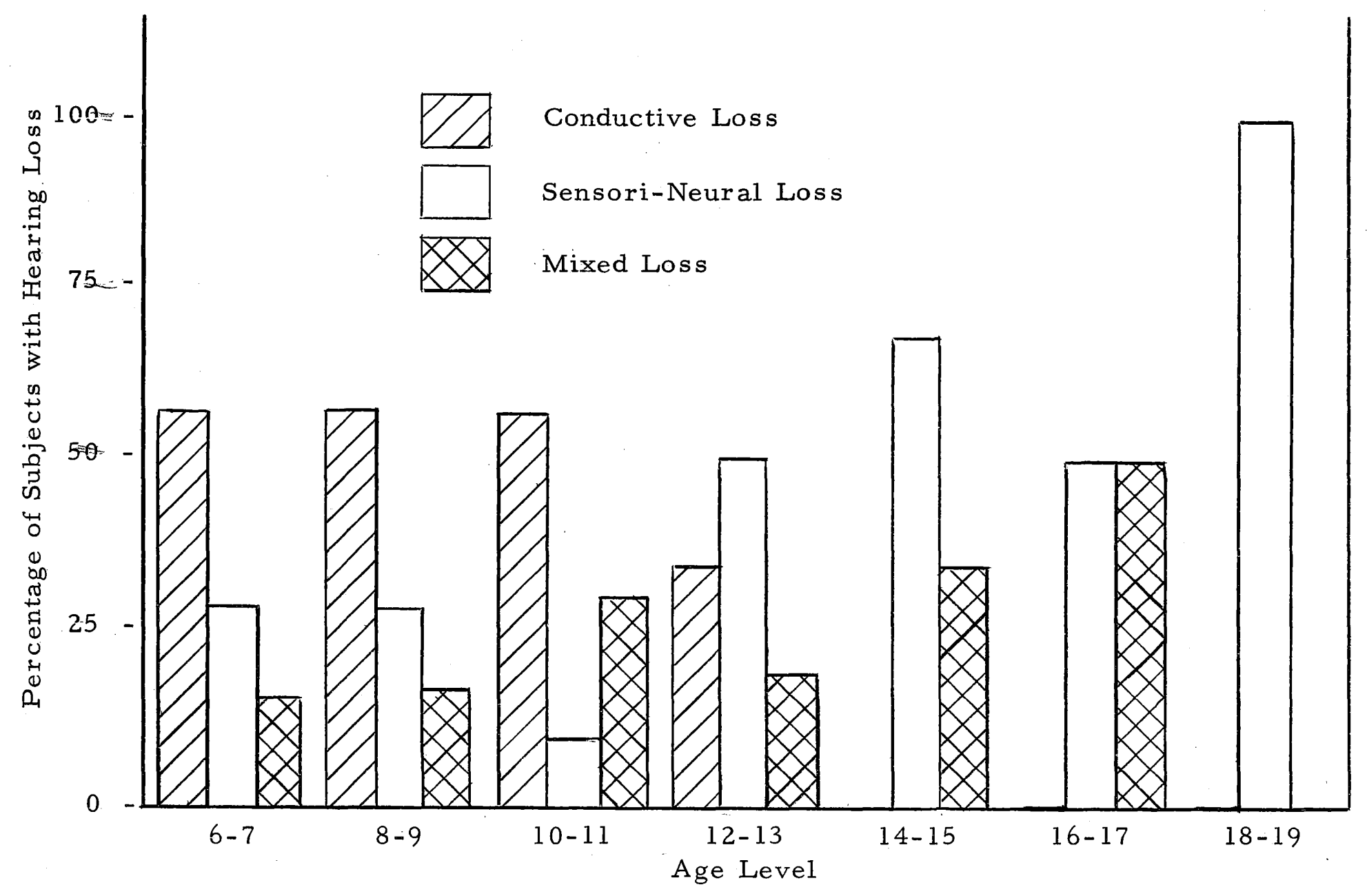

Figure 7. Percentage of subjects with hearing loss by type at each age level. 
thresholds. A primarily sensori-neural impairment was a hearing loss with no significant air-bone gap. A mixed impairment indicates some conductive component and some sensori-neural component.

The apparent pattern established in the current survey by the percentage of hearing loss type over the age levels, reveals a concentration of conductive type losses at lower age levels and a concentration of sensori-neural losses at the higher age levels. The percentage of conductive losses ranged from approximately $60 \%$ at age level 6-7 years to $0 \%$ at $18-19$ years. The sensori-neural losses ranged from approximately $15 \%$ at age level $6-7$ to $100 \%$ at $18-19$ years. 
CHAPTER VI

\section{DISCUSSION}

Some writers (e.g., Atkinson, 1960; Schlanger, 1961;

LaCrosse and Bidlake, 1964) have suggested that pure tone audiometry: is not a reliable and valid estimate of a retarded child's hearing sensitivity and, hence, have questioned previous findings of greater incidence of hearing loss among the retarded than among the nonretarded. Although the pure tone data of some investigators may be questioned, certain audiometric procedures have been demonstrated to be reasonably reliable (Lloyd, 1965a; Lloyd and Melrose, 1966; Lloyd and Reid, 1966; Lloyd and Reid, 1968; Bricker and Bricker, 1969). The current study's operant procedures were designed along the description of Lloyd and Reid (1968) and Bricker and Bricker (1969) and were obtained by examiners experienced in working with the retarded, using an appropriate environment, with equipment that was recently monitored for calibration, and the cross-checking of test data for inter- and intra-tester reliability.

Lloyd (1965a; 1965b) and Lloyd and Frisina (1965) have previously cited several reasons why they felt it reasonable to assume a higher incidence of hearing impairment among the retarded than is 
found among the nonretarded. The reasons included the high number of sensori-neural pathologies (including brain damage) and congential anomalies that are etiologically related to mental retardation, along with the frequently poor self-care skills (or habits). The fact that the higher level retardates, in general, have a lower incidence of hearing los than the more severely retarded, seems to lend face validity to the current study's findings. (See Figure 3, p. 41.)

Furthermore, since the sensory deprivation reflected by a hearing impairment may, in and of itself, cause retardation (Heber, 1961; President's Pane1, 1962; Kodman, 1963), the findings of a relatively high incidence of hearing los among the retarded seems plausible.

Rittmanic (1959) and Nudo (1965) have presented previous data that show the age of patients also to be a critical factor in the incidence of hearing impairments. An institution that has a number of older adults, especially 50 years old or more, probably; would have a higher incidence figure than would an institution or special education program primarily for children (Lloyd and Reid, 1967).

The current survey shows a decrease in hearing los incidence with an increase in age (Figure 4, p. 43); however, Stewart (1969), in a summary of audiological literature on mental retardates, has stated that while hearing impairment among normal children decreases with age, it increases with age among the mentally retarded. 
The current study's apparent contradiction to this statement can be partially explained by the abundance of higher level mental retardates (MI levels I and II) in the survey (Figure l, p. 27), since many of the higher level retardates are also at the higher age levels. The lower incidence of hearing loss in the higher level retardates coupled with the relative lack of older subjects (Figure 2, p. 28) could further explain the reverse in the trend of hearing levels in relation to age levels as described by' Stewart.

There is a paucity of information regarding the proportion of hearing losses in relation to sex. Lloyd and Reid (1967) reveal no consistent sex difference in the proportion of hearing losses; however, Fulton and Griffin (1967) and Stewart (1969) have indicated a slightly higher incidence of hearing los in males than in females. Stewart suggests that although data are lacking on the validity of male-female hearing loss ratios among the mentally retarded, the greater overall number of males diagnosed as "mentally retarded" may be one factor influencing those reports of higher incidence of hearing impairment among the mentally retarded. The current survey's slightly higher incidence of males than females with hearing loss (Figure 5 and 6, pp. 44-45) could possibly be explained by the abundance of total males over total females in the sample (Figures 1 and 2 , pp. 27-28). The use of percentages to describe the hearing losses of each sex, however, could rule out the effect of difference 
in total numbers and leave the higher incidence of hearing loss among males to chance. Lloyd and Reid (1967) do not reveal a consistent sex difference in proportion of conductive or sensori-neural hearing losses, nor does the current study.

Pantelakos (1963) found a higher incidence of patients with sensori-neural than with conductive impairments; however, these findings may be due to the ages of the subjects. Pantelakos did not specify the ages of his subjects, but the institutional population of 1, 229 patients from which they were selected included over 400 retardates older than 19 years (Lloyd and Reid, 1967). Non-retarded adults would have a higher proportion of sensori-neural than conductive impairments, while children would have a higher proportion of conductive impairments. The same age relationships to type of hearing impairment would be expected for retarded children (Pantelakos, 1963). Nudo's (1965) data support the contention that retarded children may have relatively more conductive impairments, while retarded adults may have relatively more sensori-neural impair ments. The present data reveal the same concentration of conductive hearing losses in the younger age groups (6-11 years) and sensori-neural losses in the older age groups (12-19 years). (See Figure 7, p. 46 for the se data.)

The incidence of hearing loss among the public school population of children between 6 and 19 years of age has been reported as 
ranging from approximately $3 \%$ by Weber et al. (1967) to 5\% by Newby (1958), O'Neill (1964), O'Neill and Oyer (1966). The difference between the reported percentage of loss among public school children and the present data reveals a three to six times greater incidence of hearing loss among the special education children of the Vancouver School District. 


\section{SUMMARY AND CONCLUSIONS}

\section{PROBLEM}

In order for the mentally retarded population to achieve maximum benefit from rehabilitation efforts, it is essential that a complete picture of their abilities and disabilities be obtained. Consequently, the identification of hearing loss is an integral element in any diagnostic procedure. Vancouver School District 37 has directed increased attention toward speech and language training for children in the special education classrooms for the mentally retarded; however, differential hearing diagnosis has been inadequate or totally lacking.

In order to more efficiently treat this problem, it was felt that a comprehensive investigation into the incidence and types of hearing loss of this population would provide a basis for program design. To adequately survey the previous investigations in the literature, it was advantageous to divide them into categories according to likeness of criteria used in defining "hearing loss." 


\section{METHOD}

In this survey, a heterogeneous sample of 212 retarded subjects ranging in age from 6 years, 8 months to 19 years, 9 months was audiometrically tested at four frequencies: $500 \mathrm{~Hz}, 1000 \mathrm{~Hz}$, $2000 \mathrm{~Hz}$, and $4000 \mathrm{~Hz}$. The retarded subjects encompassed MI levels I through IV on the classification system developed by the American Association on Mental Deficiency. Tests were administered at eight locations within the Vancouver School District 37 which offered adequate test environments. The criterion for hearing loss in this survey was a los of $20 \mathrm{~dB}$ or more in two or more frequencies in either ear. The audiometric procedure used in both airbone-conduction testing was the revised technique of Newhart and Reger (1945, revised 1956). Operant procedures were designed after Stewart (1970). Two examiners were used and ten test scores of each correlated at approximately .93 using the Pearson ProductMoment Correlation.

\section{RESULTS}

1. Thirty-eight of the 212 subjects hadihearing losses of 20 $d B$ or more in two or more frequencies in either ear.

2. This number established an incidence of $17.9 \%$ for this population. 
3. The present data indicate, in general, that the incidence of hearing loss is greater among the more severely retarded than among the less retarded.

4. The audiometric data depict a general trend toward a decrease in hearing loss incidence with increasing age.

5. The hearing loss incidence for males was slightly more (53.\%) than for females $(47 \%)$.

6. The pattern established by the current survey revealed a concentration of conductive losses at lower age levels and a concentration of sensori-neural losses at the higher age levels.

\section{CONCLUSIONS}

The special education classrooms of Vancouver School District 37 reveal a three to six times greater incidence of hearing los than among the normal classrooms of the district. The concentration of conductive losses at lower age levels leads to a recommendation that hearing levels be screened each year up to age 12 . 


\section{REFERENCES}

Anderson, D., Mental retardation and hearing impairment. Unpublished manuscript, Oregon State Board of Health (1964).

Atkinson, C.J., Perceptive and Responsive Abilities of Mentally Retarded Children as Measured by Several Auditory Threshold Tests. U.S. Office of Educ. Coop. Research Project No.

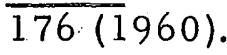

Beasley, W. C. , General problems of deafness in the population. Laryngoscope, 50, 157-60 (1940).

Birch, J.W., and Matthews, J., The hearing of mental defectives: its measurement and characteristics. Amer. J. ment. Defic., 55, $384-93(1951)$.

Bricker, W. A., and Bricker, D., A programmed approach to operant audiometry for low-functioning children. J. Speech Hearing Dis., 34, 312-19 (1969).

Doerfler, L. G., and Eagles, E. L., Hearing in children: acoustic environment and audiometer performance. J. Speech Hearing Res. , 4, 149-63 (1961).

Foale, M. , and Paterson, J. W., The hearing of mental defectives. Amer. J. ment. Defic., 59, 254-58 (1954).

Frisina, D. R., and Lloyd, L. L., Summary and conclusions. In L. L. Lloyd and D. R. Frisina, (Eds.), The Audiological Assessment of the Mentally Retarded: Proceedings of a National Conference. Parsons, Kansas: Speech and Hearing Dept., Parsons State Hospital and Training Center (1965).

Fulton, R. T., and Griffin, C. S., Audiological-otological considerations with the mentally retarded. Mental Retardation, $\underline{5}$, $26-31$ (1967).

Gardner, J.W., President's Committee on Mental Retardation, A First Report. Wn., D.C., U.S. Government Printing Office, 0-269-237 (1967). 
Goldstein, R., and Kramer, J.C., Factors affecting thresholds for short tones. J. Speech Hearing Res., 3, 249-56 (1960).

Heber, R., A manual on terminology and classification in mental retardation. Amer. J. ment. Defic., Monogr. Suppl. (1959).

Heber, R., Modifications in the manual on terminology and classification in mental retardation. Amer. J. ment. Defic. 65, 499-500 (1961).

Hirsh, I. J., The Measurement of Hearing. N. Y.: McGraw-Hill (1952).

Holmes, R. W., and Peletier, L. P. , Jr., The Pineland Hospital Speech and Hearing Survey, 1964-1966: Part Two. Pineland Hospital and Training Center, Pownal, Maine (1966).

Horowitz, F.D., I. Partial and continuous reinforcement of vocal responses using candy, vocal, and smiling reinforcers among retardates. In F. L. Darley, (Ed.), Language studies of mentally retarded children. J. Speech Hearing Dis. Monogr. Suppl. No. 10, 55-69 (1963).

Johnson, P. W., and Farre11, M. J., Auditory impairments among resident school children at Walter E. Fernald State School. Amer. J. ment. Defic., 62, 640-43 (1958).

Kodman, F., Jr., Sensory processes and mental deficiency. In N.R. Ellis, (Ed.), Handbook of Mental Deficiency. N. Y. : McGraw-Hill (1963).

Kodman, F., Jr., Powers, T.R., Weller, G. M. , and Philip, P. P. , Pure tone audiometry with the mentally retarded. Except. Child., 24, 303-05 (1958).

La Crosse, E. L., and Bidlake, H., A method to test the hearing of mentally retarded children. Volta Rev. , 66, 27-30 (1964).

Lillywhite, H. S., and Bradley, Doris P., Communication Problems in Mental Retardation: Diagnosis and Management. N. Y.: Harper \& Row (1969).

Lloyd, L. L., A comparison of selected auditory measures on normal hearing mentally retarded children. Unpublished Ph. D. dissertation, University of Iowa (1965a). 
Lloyd, L. L., The new audiology program at Parsons State Hospital and Training Center. Hearing News, 33, 5-7 (1965b).

Lloyd, L. L., and Frisina, D. R., (Eds.), The Audiologic Assessment of the Mentally Retarded: Proceedings of a National Conference. Parsons, Kansas: Speech and Hearing Dept., Parsons State Hospital and Training Center (1965).

Lloyd, L. L. , and Melrose, J., Reliability of selected auditory responses of normal hearing mentally retarded children. Amer. J. ment. Defic., 71, 133-43 (1963).

Lloyd, L. L., and Reid, M. J., The reliability of speech audiometry with institutionalized retarded children. J. Speech Hearing Res., 9, 450-55 (1966).

Lloyd, L. L., and Reid, M. J., The incidence of hearing impair ment in an institutionalized mentally retarded population. Amer. J. ment. Defic., 71, 746-63 (1967).

Lloyd, L. L., and Reid, M. J., The reliability of pure tone audiometry with institutionalized MR children. Parsons Demonstration Project Report, No. 51 (1968).

Lloyd, L. L., Reid, M. J., and McManis, D. L., Pure tone reliability of a clinical sample of institutionalized MR children. Amer. J. ment. Defic., 73, 279-82 (1968).

Lloyd, L. L., Spradlin, J.E., and Reid, M. J., An operant audiometric procedure for difficult-to-test patients. J. Speech Hearing Dis. , 33, 236-45 (1968).

Marshall, N., Oral deviations and speech and language disorders in 200 mentally retarded children. Unpublished manuscript, University of Oregon Medical School (1967).

Naughton, R.F., Clinical bone-conduction audiometry. Arch. Otolaryng. , 66, 281-98 (1961).

Newby, H. Audiology. N. Y.: Appleton-Century-Crofts (1964).

Newhart, H., and Reger, S. N., Syllabus of Audiometric Procedures in the Administration of a Program for the Conservation of Hearing of School Children. Amer. Acad. Ophth. Otol. (1945). 
Newhart, H. , and Reger, S. N. , Manual for a School Hearing Conservation Program. Amer. Acad. Ophth. Otol. (1956).

Nudo, L. A., Comparison by age of audiological and otological findings in a state residential institution for the mentally retarded: a preliminary report. In L. L. Lloyd and D. R. Frisina (Eds.), The Audiologic Assessment of the Mentally Retarded: Proceedings of a National Conference. Parsons, Kansas: Speech and Hearing Dept., Parsons State Hospital and Training Center (1965).

O'Neill, J. J., The Hard of Hearing. Englewood Cliffs, N. J.: Prentice-Hall (1964).

O'Neill, J. J. , and Oyer, H. J., Applied Audiometry. N. Y.: Dodd, Mead and Co. (1966).

Pantelakos, C. G. , Audiometric and otolaryngologic survey of retarded students. N.C. Med. J., 24, 238-42 (1963).

President's Panel, A Proposed Program for National Action to Combat Mental Retardation. Washington, D. C. : Supt. of Documents (1962).

Rigrodsky, S. , Prunty, F., and Glovsky, L., A study of the incidence, types, and associated etiologies of hearing loss in an institutionalized mentally retarded population. "Train. Sch. Bul1. , 58, 30-43 (1961).

Rittmanic, P.A., Hearing rehabilitation for the institutionalized mentally retarded. Amer. J. ment. Defic., 63, 778-83 (1959).

Robinson, H. B., and Robinson, N. M., The Mentally Retarded Child. N. Y.: McGraw-Hill (1965).

Schlanger, B., The Effects of Listening Training on the Auditory Thresholds of Mentally Retarded Children. U.S. Office of Educ. Coop. Research Project No. 973, Jan. (1961).

Schlanger, B. B., and Gottsleben, R. H., Testing the hearing of the mentally retarded. J. Speech Hearing Dis., 2l, 489-93 (1956).

Siegenthaler, B., and Krzywicki, D., Incidence and patterns of hearing loss among the adult mentally retarded population. Amer. J. ment. Defic., 64, 444-49 (1959). 
Stewart, E. L., A summary of variables associated with audiometric testing of mentally retarded children, and a report on use of vicarious learning in the testing situation. Unpublished paper, Portland State University (1969).

Stewart, E. L., A comparison of object dropping and echoic vocalizing as response modes to pure tone stimuli among mentally retarded children. Unpublished master's thesis, Portland State University (1970).

Studebaker, G. A., Placement of vibrator in bone-conduction testing. J. Speech Hearing Res., 5, $321-31$ (1962).

A Study of Child Services in the Portland, Oregon, Public Schools. Mimeographed publication of the Department of Research and Measurements. Portland, Ore., 275-88 (1963).

Webb, C.E., Kinde, S. W., Weber, B.A., and Beedle, R. K., Procedures for Evaluating the Hearing of the Mentally Retarded. U.S. Office of Educ. Coop. Research Project No. 1731, Jan. (1964).

Webb, C. E., Kinde, S. W., Weber, B. A., and Beedle, R. K., Incidence of hearing loss in institutionalized mental retardates. Amer. J. ment. Defic., 70, 563-68 (1966).

Weber,.E. W., Mentally Retarded Children and Their Education. Springfield, Ill.: Charles C. Thomas (1963).

Weber, H. J., McGovern, F.J., and Zink, D., An evaluation of 1000 children with hearing loss. J. Speech Hearing Dis., 32, $343-53(1967)$.

Young, N. B. , Speech and hearing problems among mentally retarded children. Unpublished manuscript, University of Oregon Medical School (1965). 
APPENDIX 


\section{APPENDIX}

\section{DEFINITION OF TECHNICAL TERMS AND ABBREVIATIONS}

\section{AUDIOLOGICAL TERMS}

Air-bone gap: The difference in decibels between the hearing levels for a particular frequency as determined by air-conduction and by bone-conduction.

Air-conduction: The process by which sound is conducted to the inner ear through the air in the outer ear canal as part of the pathway.

Bone-conduction: The process by which sound is conducted to the inner ear through the cranial bones.

Conductive hearing loss: A hearing impairment due to interference with the acoustic transmission of sound to the sense organ, usually in the outer or middle ear. In pure conductive hearing loss, the hearing threshold levels measured by bone-conduction are usually normal and the air-bone gaps are large.

dB: The abbreviation for the term decibel, which is $1 / 10$ of a bel. The decibel expresses the ratio of two values of power. It is a useful measure for comparing the power of two sounds.

HL: The abbreviation for the term hearing level or hearing loss, which is the deviation from the established threshold level represented by a zero reading on the hearing loss dial of the audiometer.

Hz: The abbreviation for the term Hertz, after the German physicist, Heinrich Hertz, about 1886. It is equivalent to cycles per second (cps), referring to the number of double sine waves or complete cycles occurring in a vibrating body each second.

Masking: The amount by which the threshold of audibility of a sound is raised by the presence of another (masking) sound. The unit customarily used is the decibel (dB). 
Mixed hearing loss: A combination of conductive and sensori-neural hearing loss. This term is restricted by custom to peripheral hearing losses.

Pure tone: A simple tone or sound wave, the instantaneous sound pressure of which is a simple sinusoidal function of the time.

Screening (audiometric): A method or group of methods designed to separate individuals whose thresholds lie above normal from those whose thresholds lie at or below normal threshold.

Both speech and pure tone are used as test signals.

Sensori-neural hearing loss: A hearing impairment due to abnor mality of the sense organ, the auditory nerve or both. Some or all hearing levels by bone-conduction are abnormal, but the air-bone gaps are small or absent.

Sound field: A region containing sound waves. Sound field audiometric testing introduces either pure tone or speech signals to the subject by means of air-conducted sound waves without the use of earphones or bone-conduction oscillator, usually within a confined room especially designed for that purpose.

Threshold testing: Determination of the lowest intensity of a stimulus required to produce a sensation in a subject or elicit a response from him.

\section{OPERANT TERMS}

Discriminative Stimulus $\left(S^{D}\right)$ : A stimulus in whose presence a particular bit of operant behavior is highly probable, because the behavior has been previously reinforced in the presence of that stimulus.

Operant conditioning: The science of behavior in which the frequency of occurrence of bits of behavior is modified by the consequences of the behavior.

Positive reinforcement: Stimuli following a response that causes the response rate to increase as a function of the presentation of that stimulus. 
Stimulus control: The stage in operant conditioning at which an $S^{D}$ will, with a high degree of probability, control a particular operant (response). The high frequency of the operant in the presence of the $S^{D}$ is achieved through the frequent accompaniment of the $\mathrm{S}^{\mathrm{D}}$ with the occurrence of the operant and subsequent reinforcement of this contingency.

\section{EDUCATIONAL TERMS}

Educable mentally retarded: Those individuals having IQ scores of between 50-75 and having, or having a prognosis that they will have, learning difficulties in the regular grades.

Mental retardation: According to the American Association on Mental Deficiency (AAMD), mental retardation refers to subaverage general intellectual functioning which originates during the developmental period and is associated with impairment in adaptive behavior.

Measured intelligence level (MI): The American Association on Mental Deficiency has classified the retarded group in five categories: I--borderline; II--mild; III--moderate; IV-severe; and V--profound. These categories carry less stigma and have significance for differential educational treatment.

Special education: Special education services embody three elements worthy of note: (1) trained professional personnel possessing special competencies for serving a certain type or types of exceptional children; (2) special curricular content for certain areas of exceptionality, particularly for the mentally retarded; and (3) special facilities including such special features as ramps, group hearing aids, braille books, library materials, and visual aids.

Trainable mentally retarded: Those individuals who are not likely to acquire sufficient skills in school to operate beyond grade 4 , the standard for literacy. 